\section{A COMPARAÇÃO ENTRE A ÓPERA ITALIANA E A FRANCESA: RAGUENET E A IRREDUTIBILIDADE DE DUAS TRADIÇÕES.}

O Paralelo entre Italianos e Franceses no que concerne à Música e às Óperas é fruto de uma viagem à Itália realizada pelo abade François Raguenet (1660-1723), acompanhando o sobrinho do Cardeal de Bouillon nos anos de 1697 e 1698. Como tantos outros viajantes, nas mais diversas épocas, o país causou marcante impressão em Raguenet, gerando no autor grande entusiasmo pela arte italiana, o que pode ser depreendido em duas de suas publicaçoes: Les Monumens de Rome, ou descriptions des plus beaux ouvrages de peinture, de sculpture et d'architecture, qui se voyent à Rome, et aux environs, etc. ${ }^{1}$, e o já mencionado Paralèle [sic] des Italiens et des François en ce qui regarde la musique et les opéra (RAGUENET, 1702). O autor já havia escrito sobre outros temas, como a história da vida de Cromwell ${ }^{2}$, e um discurso sobre o martírio, que ganhou o prêmio de eloquência da Academia Francesa $^{3}$ e ele também é lembrado por outras obras ${ }^{4}$, mas seu Paralelo tem fundamental importância, entre outras razões, por enunciar diversas questões sobre a música e a ópera que serão debatidas ao longo de todo o século XVIII.

Dentro do espírito da viagem à Itália, podemos ler o livro de Raguenet sobre as óperas como o registro de impressões de um amador, no sentido próprio do termo. Durante a leitura, percebe-se o fascínio e o encantamento pela ópera italiana, em todos os seus aspectos: a música, os cantores, a vocalidade própria dos cantores italianos, a orquestração, os cenários, ou seja, o conjunto de elementos que compóem o espetáculo, sem se prender a questôes de definição do gênero dramático (literário ou musical). O que seduz o abade Raguenet é o caráter inebriante do espetáculo ${ }^{5}$, que seria, para os franceses, algo que ultrapassaria os limites do decoro, da politesse e do bom gosto (FADER, 2003). E é partindo do pressuposto do prazer que o autor discorre sobre os dois tipos de ópera por ele
1. Amsterdã, 1701. Publicado novamente com modificações em 1765 (RAGUENET, 1765). Sobre a viagem, foi também publicado o livro L'éducation du jeune comte $D$. $B^{* * *}$, ses amours avec Émilie de $T^{* * *}$ et ses voyages, selon ses propres mémoires où sont recueillis grand nombre d'histoires ... et découvertes d'antiquités très curieuses, accompagnées de plus de cent estampes des plus beaux monumens de Rome par Mr. de Raguenet. Londres: M. Chastel, 1765.

\section{Histoire d'Olivier \\ Cromwel, Paris, Chez C. Barbin: 1691, reimpressa diversas vezes.}
3. Discours [sur le mérite et la dignité du martyre] qui a remporté le prix d'éloquence, par le jugement de l'Académie française, en l'année mil six cent quatre-vingt neuf. Paris: G. Barbin, 1689. 
4. Além das já mencionadas, listamos a seguir os títulos de autoria de Raguenet: Histoire de l'Ancien Testament. Paris: C. Barbin, 1689 (e várias outras ediçôes); Histoire du Vicomte de Turenne.

Haia: J. Neaulme, e várias outras edições; Syroes et Mirame, histoire persane. Paris: C. Barbin, 1692. Para uma discussão sobre alguns aspectos de sua obra, cf. Storer (1945).

5. A resenha do livro, publicada nas Mémoires de Trevoux (1702, p. 345), insiste que a descrição da reação do público italiano, que interrompia os músicos com gritos e aplausos, soava como "hiperbólica", mas deveria ser verdadeira. Para um exemplo de um debate mais tradicional sobre uma ópera, vejase a polêmica em torno da Alceste de Lully e Quinault. Cf. BROOKS; NORMAN, ZARUCCHI (1994).

6. "Espetáculo cênico" é a tradução de Eudoro de Sousa (ARISTÓTELES, 1986, p.110). Valentín García Yebra (ARISTÓTELES, 1992, p.145-146) opta por "decoración del espectáculo", justificando sua opção na nota 106 (p.

265) conhecidos: a para ele recém descoberta ópera italiana e a tragédia lírica (tragédie lyrique) francesa. Por suas peculiaridades, trata-se de um texto que destoa de grande parte da reflexão sobre ópera, uma vez que Raguenet enumera e discute as partes constitutivas do espetáculo, sem se deter em um debate literário que constantemente apelava para as poéticas clássicas ${ }^{6}$.

Em sua Poética, Aristóteles reconhece a aulética e a citarística como artes imitativas e trata, em alguns momentos, da música em geral como elemento constitutivo das representaçôes teatrais. $\mathrm{Na}$ complexa passagem da Poética 6, o estagirita, justamente no momento de definir a tragédia, indica o "espetáculo cênico"7 (ópsis) como parte constitutiva da tragédia, para não mais tratar do assunto em detalhe. Aponta como partes da tragédia o mito, o caráter, a elocução (léxis), o pensamento, o espetáculo e a melopéia (mélos), sendo que em 1450b 17 o autor dirá que "a melopeia (melos) é o principal ornamento". É possível compreender aqui por que razão a posteridade viu em Aristóteles a preferência pela léxis, em detrimento da ópsis ${ }^{8}$. Mais adiante, em $1450 b$ 18-21, Aristóteles afirma que o espetáculo é o mais "emocionante" (psycagogikón), lembrando porém que é "o menos artístico e menos próprio da poesia", sem explicar o porquê. Nessa breve passagem podemos reconhecer aquilo que será a maior dificuldade para se compreender as óperas a partir do início do século XVII: a tensa relação entre texto, música e os demais elementos constitutivos do espetáculo. A opção pela léxis, em detrimento da ópsis, é um tipo de preconceito teórico que será assumido pela maior parte dos escritores que refletiram sobre a ópera, a qual se torna, consequentemente, um gênero "monstruoso". De acordo com essa visão, tal monstruosidade necessitará de regras que corrijam um defeito "essencial" da ópera: a presença da música em todo o espetáculo gera problemas das mais variadas ordens e, dependendo do autor, conduziria à recomendação de extinção do espetáculo ou à proposta de remediar alguns de seus defeitos.

Na Poética horaciana, outro texto capital para o pensamento sobre a poesia e o teatro, encontramos nos versos 202219 as normas concernentes à música, considerada um dos elementos da poesia dramática. A recomendação principal é que a música se mantenha severa e submissa ao texto, o que, podemos depreender, não acontecia de fato. A visão horaciana, no que respeita ao uso da música, enxerga a decadência 
nos espetáculos em que a música ultrapassou os limites que lhe eram próprios, tendendo apenas a agradar o vulgo 9 . Desse modo, já em Horácio encontramos uma visão nostálgica de um momento de ouro, em que a música desempenhava um papel adequado no conjunto do espetáculo. Tal sentimento aparecerá em diversas obras que criticam a presença da música, sempre apontando para um passado real ou imaginário. Podemos ainda lembrar outras recomendações horacianas, como a vocação nobre do poeta, a constante referência aos dramas gregos, a ênfase nas questóes morais, o decoro das apresentaçōes e a necessidade de uma crítica atenta. Tudo isso certamente comporá boa parte das críticas francesas e italianas sobre ópera nos séculos XVII e XVIII.

Como dissemos anteriormente, Raguenet parece escapar de tal abordagem, já que seu livro sabe muito mais aos relatos de viagem do que a um tratado sobre ópera. Contudo, tanto pelos temas enunciados, como pela polêmica que se seguiu após a publicação do livro e pela divulgação do texto em inglês e alemão, a pequena obra de Raguenet pode ser encarada como um ponto de inflexão na longa tradição de pensamento sobre a ópera ${ }^{10}$. A proposta inicial soa modesta, em certo sentido, até mesmo ingênua, já que, aparentemente, o autor pretende comparar, de uma maneira que apresenta como neutra, a música e a ópera dos italianos e dos franceses, reconhecendo, desde o início, que em determinados aspectos, uns levam vantagem sobre os outros. A ideia do "paralelo", como já indicava Fubini (1991, p. 46), é um eco do Parallèle des Anciens et des Modernes de C. Perrault ${ }^{11}$, que tantas polêmicas suscitou na França na segunda metade do século XVII ${ }^{12}$. De qualquer modo, Raguenet pretende estabelecer comparações entre os franceses e os italianos e, a princípio, temos a impressão de que se trata de uma mera constatação dos fatos. Contudo, através do desenvolvimento do texto, percebemos que aquilo que o autor teria a dizer de positivo sobre a ópera francesa dura muito pouco: à página 23 da edição original, o autor afirma: "Eis tudo o que pode ser dito a favor da França, no que concerne à música e às óperas. Vejamos agora o que pode ser dito a favor da Itália nessas duas coisas. A partir daí, procede ao exame da ópera italiana, justamente para encontrar suas vantagens até o final do livro, que tem 124 páginas.
7. Além das já mencionadas, listamos a seguir os títulos de autoria de Raguenet: Histoire de l'Ancien Testament. Paris: C. Barbin, 1689 (e várias outras edições); Histoire du Vicomte de Turenne. Haia: J. Neaulme, e várias outras edições; Syroes et Mirame, histoire persane. Paris: C. Barbin, 1692. Para uma discussão sobre alguns aspectos de sua obra, cf. Storer (1945).

8. A linhagem que privilegia o texto e desconsidera os demais elementos é longuíssima na tradição ocidental, justamente porque, na visão de Aristóteles, o texto deveria garantir a qualidade trágica. Para uma visão diferente, que tenta mostrar os "equívocos" da posteridade, cf. SCOTT (2000).

9. Rostagni, em seu comentário sobre o trecho, recomenda alguma cautela quanto à ênfase na degeneração, lembrando que "qui Or. indulge più che altrove allo spirito del Vecchio Catone che alla santità dei primitivi costumi opponeva in ogni cosa la corruzione dei nuovi" (HORÁCIO, [19-], p.60-61).

10. Sobre a importância do texto de Raguenet dentro de um contexto mais amplo das relações entre música e filosofia, cf. TOMÁS (2004, p. 70-74). 
Imediatamente é possível depreender a preferência de Raguenet pelos italianos, o que com segurança soava como uma provocação aos franceses, mesmo que esta não tenha sido a intenção primeira do autor. Mas, antes das polêmicas suscitadas, é necessário destacar algumas dificuldades que prontamente se manifestam na empreitada. Ao procurar estabelecer um paralelo entre franceses e italianos, no que concerne à ópera, percebemos que o termo ópera tem significados muito diferentes quando aplicados às duas tradições de espetáculos teatrais com música. Certamente a ópera francesa, a tragédie lyrique, muito deve à ópera italiana, tanto pelas apresentações de espetáculos italianos na França a partir da década de $1640^{13}$, como pela própria origem italiana de Lully, bem como por diversos outros elementos constitutivos do espetáculo. Entretanto, a tragédie lyrique aproveita outras tradições francesas e, acima de tudo, reporta-se a um diverso contexto social: ela serve para enaltecer o rei e faz parte de uma série de atividades existentes na corte francesa. Já a ópera italiana, especialmente a veneziana, está ligada a teatros públicos (abertos ao público pagante), com diversas peculiaridades. Desse modo, percebe-se que, apesar de o termo ópera ser usado tanto para o caso italiano como para o caso francês, existiam diversos pontos discordantes que não permitiriam um paralelo muito claro.

O mesmo pode ser verificado em diversas palavras italianas que não encontram uma tradução apropriada para o francês, pois nem sempre há equivalência entre os termos, os usos e as tradições musicais. $\mathrm{Na}$ leitura do dicionário de Sébastien de Brossard ([1708]), já se nota a preocupação do autor em estabelecer a equivalência dos termos musicais nas diversas línguas (grego, latim, italiano e francês), indicando, contudo, em primeiro lugar, os termos italianos para depois encontrar seus equivalentes em francês. Uma primeira dificuldade, no caso de Raguenet, diz respeito à classificação das vozes francesas. Os termos de origem italiana (soprano, contralto, tenor, barítono e baixo, com distinções intermediárias), não são exatamente equivalentes aos franceses (dessus, haute-contre, taille, basse-taille, basse-contre). Certamente a equivalência está na posição relativa das vozes, oriunda da prática polifônica, em uma classificação que vai da mais aguda à mais grave. O problema é que nem a extensão das vozes nem o uso que elas têm 
nas duas tradições tem uma equivalência precisa. $\mathrm{O}$ caso mais difícil é certamente o do haute-contre ${ }^{14}$.

A voz de haute-contre é uma voz masculina aguda utilizada nos papéis principais das óperas de Lully em diante. Ela é, em certa medida, correspondente ao tenor italiano, mas logo se percebe uma grande diferença: a voz de tenor, na tradição italiana do século XVII, ainda não estava associada aos protagonistas, mas sim, aos personagens cômicos (masculinos ou femininos). E de qualquer maneira, como já visto, o haute-contre não é um tenor, no que respeita à extensão vocal. No dicionário de Brossard, nem sempre encontramos as pistas necessárias para esclarecer este ponto. Na definição de "alto", o autor indica que "encontramos com frequência [...], em latim, Altus, ou contra-tenor, ou simplesmente contra. Quer dizer haute-contre" (BROSSARD, [1708], p. 9). Em "mezzo-soprano", lemos: "quer dizer demi-dessus ou haute-contre que vai muito alto" (BROSSARD, [1708], p. 59). Assim, a princípio, podemos entender o haute-contre como uma voz masculina que se assemelha ao contralto ou ao mezzo-soprano, masculino ou feminino. Ao tratar da voz de tenor (taille), Brossard faz uma classificação dessas vozes, distinguindo hautes ou premières tailles, de tailles naturelles, communes, mytoyennes ou simplesmente tailles, além de basse-tailles ou seconde tailles e concordants, estes últimos "confundidos" com o barítono. O

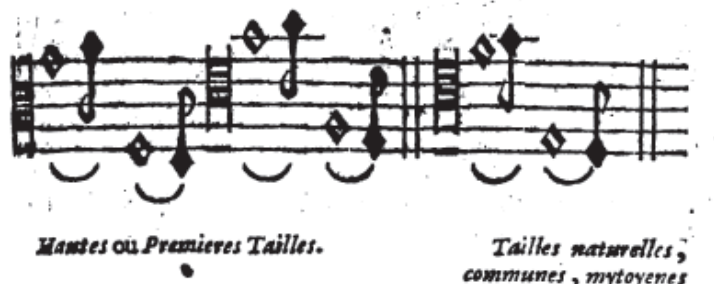

communes, mytoyenes ou fimplement Tailtes.

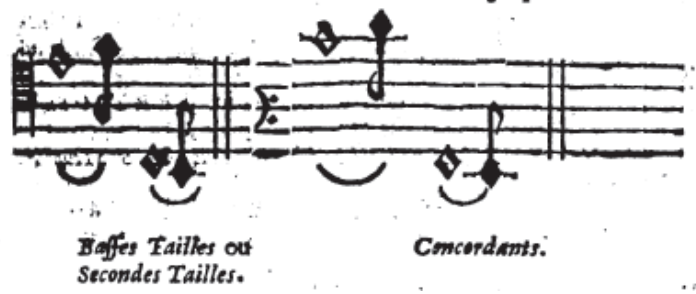

(BROSSARD, [1708], p.177)

próprio Raguenet, na defesa de seu paralelo, afirma que os italianos têm tailles, na verdade, pensando em tenores: 
16. Trata-se da ópera La Rinovata Camilla, Regina de’ Volsci, música de G.

Bononcini e texto de $S$. Stampiglia. Cf. FRANCHI (1988, p. 726).

17. "Aquela das quatro partes da música que está entre o dessus e o taille".

Dictionnaire de l'Académie française (1694, p.558).

18. "HAUTE-CONTRE, altus ou contra; a parte da música que pertence às vozes de homens mais agudas ou mais altas, por oposição a basse-contre, que está para as mais graves ou mais baixas. [...] Nas óperas italianas, esta parte que eles chamam contralto, é com freqüência cantada por mulheres; enquanto os dessus mais agudos são comumente cantados por homens destinados desde a infância para este uso" (D'ALEMBERT;

DIDEROT, 1751-1772, v. 8, p. 70-71).

19. "Basse-taille esteve na moda durante todo o tempo em que Thevenard permaneceu no teatro; mas os compositores de agora fazem os papéis mais brilhantes para hautecontre. [...] Os mágicos, os tiranos, os amantes odiados são comumente basses-tailles; as mulheres parecem ter decidido, não se sabe por que, que o haute-contre deve ser o amante favorito; elas dizem que é a voz do coração; sons másculos e fortes sem dúvida alarmam a delicadeza delas. $\mathrm{O}$ sentimento, este ser imaginário de que tanto se fala, sem o definir, sem o conhecer, o
Os Italianos têm Tailles como nós; e eu nunca ouvi, em nenhum lugar, um mais belo do que o do ator que fazia o personagem de Mécio na ópera Camila, representada em Roma no Teatro Capranica em 1698 (RAGUENET, 1705, p. 135) ${ }^{16}$.

A questão apenas se complica ao percorrermos outros dicionários e a Encyclopédie. O dicionário da Academia Francesa indica apenas a posição da voz no contraponto ${ }^{17}$. Na Encyclopédie, o termo aparece em diversos verbetes: na própria definição ${ }^{18}$, na definição de basse-taille, indicando que a voz de haute-contre é preferida às demais ${ }^{19}$, em verbetes sobre as partes da música e sobre instrumentos e também no verbete étendue, no qual é apresentada a extensão desse tipo de voz:

Haute-contre: clave de dó na terceira linha. Sua extensão deve ser desde o dó em baixo da clave até o dó acima dela; o que perfaz duas oitavas inteiras, ou doze tons (D'ALEMBERT; DIDEROT, 1751-1772, v. 6, p. 46).

Rousseau, em seu dicionário de música, indica a equivalência no contralto italiano (que seria um bas-dessus), classifica a voz de não natural e diz que o tenor seria o taille ou haute-taille ${ }^{20}$. A confusão continua na parte musical da Encyclopédie, publicada por Framéry e Ginguené, que retomam e comentam os verbetes de Rousseau. Em "Contralto" afirma Framéry:

Palavra italiana que responde à nossa palavra haute-contre; mas as duas vozes, contudo, não são as mesmas e seu diapasão é assaz diferente [...] O haute-contre [...] é uma voz de um homem em toda a extensão do termo, a quem a natureza deu uma voz clara e que se eleva facilmente em direção ao alto" (FRAMERY; GINGUENÉ, 1791, t. 1, p. 315).

E no verbete Haute-contre, no comentário de De Momigny, lê-se:

A voz de haute-contre torna-se mais rara a cada dia [...]; seu timbre não é o do alto ou do tenor, assim como o timbre do violoncelo não é o da viola nem das duas cordas mais graves do violino e não é substituível pelo bas-dessus das mulheres nem pelas vozes dos musici [i.e., castrados], cujo efeito é completamente 
diferente (FRAMERY; GINGUENÉ; DE MOMIGNY, 1818, t. 2, p. 37).

Desse modo, fica patente a confusão dos termos que, na verdade, reflete a irredutibilidade de uma prática à outra. Mas o caso mais curioso pode ser encontrado no Dictionnaire dramatique de J.-M. B. Clément, no verbete sobre Dumény, cantor que executou os principais papéis de haute-contre de Lully: "era o nome de um ator da ópera, morto em 1715. [...] Ele passou por haute-contre, mas era apenas um taille dos mais agudos" (CLÉMENT, 1784). Ou seja, o cantor que criou os principais papéis do repertório francês, que lançou as bases para o desenvolvimento de toda a ópera no país ... não seria um haute-contre! Assim, percebemos que o haute-contre não tem uma verdadeira correspondência na classificação italiana, sendo aliás um tipo de voz muito complexo, desde sua definição até seu emprego hoje em dia nas encenações e gravações do repertório francês dos séculos XVII e XVIII ${ }^{21}$.

Esta dificuldade de tradução do termo haute-contre pode, em princípio, ser estendida às outras vozes, às famílias de instrumentos (violons, violes, etc.) e à sonoridade das orques$\operatorname{tras}^{22}$. Além disso, os diversos termos musicais relacionados à ornamentação (trillo, passagio, cadenza, coloratura), ou mesmo das partes constitutivas do espetáculo (ária, recitativo, arioso, etc.) não têm correspondência exata nas duas práticas. Há também aquelas inexistentes na tradição italiana, como os balés, as entrées e os divertissements, de tamanha relevância na ópera francesa. Desse modo, para além de um problema de terminologia, percebem-se estruturas essencialmente diferentes e podemos indagar-nos sobre a própria possibilidade de um paralelo entre a música italiana e francesa, uma vez que as condições são tão diferentes. O objetivo não é absolutamente desmerecer o texto de Raguenet, mas sim, mostrar o quão distintas são as duas tradiçōes e que, partindo-se de uma comparação entre coisas dessemelhantes, uma delas certamente sairá prejudicada. E, se o texto de Raguenet se insere na tradição dos paragoni, fica mais clara a intenção de determinar qual é a prática superior.

Mas quais elementos Raguenet utiliza na comparação? O texto não é sistemático - nem tem a pretensão de sê-lo - con- sentimento pronunciou-se a favor dos hautes-contre. Quando novamente se der crédito a um novo basse-taille, quando aparecer outro Thevenard, este sistema ruirá por si mesmo e verossimilmente nos serviremos mais uma vez do sentimento para provar que o hautecontre nunca foi a voz do coração" (D'ALEMBERT; DIDEROT, 1751-1772, v. 2, p. 121).

20. "HAUTE-CONTRE, ALTUS OU CONTRA.

Aquela das quatro partes

da música que pertence

às vozes de homens mais agudas ou mais altas, por oposição a basse-contre que está para as mais graves ou mais baixas. / Na música italiana, esta parte, que eles chamam de contralto e que responde a hautecontre, é quase sempre cantada por bas-dessus, sejam mulheres ou castrati. Com efeito, haute-contre em voz de homens não é nada natural; é necessário forçá-la para alcançar esta afinação [diapason]; o que quer que se faça, ela tem sempre aspereza [aigreur], e raramente, justeza" (ROUSSEAU, 1826, p. 437).

21. Para outras discussões a respeito desse tipo de voz, cf. CYR (1977) e ZASLAW (1974). 
22. N. Zaslaw, em sua busca de uma definição para o termo orquestra, lembra-nos que, mesmo não existindo algo como uma "orquestra barroca", "pode fazer sentido falar na orquestra de Lully, na de Handel em Londres, de uma orquestra romana, de uma orquestra vienense e assim por diante" (ZASLAW, 1988, p. 485). Isso nos interessa diretamente, pois realça as diferenças entre as práticas musicais francesas (de Lully) e dos diversos espetáculos a que Raguenet assistiu na Itália, com instrumentação variada e características próprias. tudo, logo ao início, ele nos dá uma lista de itens a serem considerados:

Mas há muitas coisas que devem ser especificadas para tal fim: a língua italiana e a língua francesa, das quais uma pode ser mais favorável do que a outra para a música; a composição das peças de teatro que os músicos põem em música; a qualidade dos atores; a dos instrumentistas; as diferentes espécies de voz; o recitativo; as árias; as sinfonias; os coros, as danças, as máquinas, as decoraçôes e todas as outras coisas que entram na composição das óperas e que contribuem à perfeição do espetáculo. Pois é preciso examinar todas as coisas em particular para bem julgar aquelas em que os italianos ou os franceses se sobressaem (RAGUENET, 1702, p. 3-5).

Note-se que, na continuação, o autor não adota a sequência da proposta inicial, tratando sim das "peças", ou seja, dos libretos e enunciando prontamente que as francesas são muito superiores. Neste momento, tem-se a impressão de que a vantagem dos franceses seria interminável. Conhecendo-se a trajetória da reflexão sobre ópera através dos séculos, com a constante preferência pelos libretos e pela estrutura poético- literária, teríamos a certeza de que toda comparação já estaria decidida a partir daqui. Isso porque justamente a tradição não só insistiu na primazia da léxis, como já foi visto, mas também apontou, com alguns momentos de exceção, a obra de Quinault como modelo inequívoco para a resolução de muitos dos problemas da ópera. Claro, não devemos esquecer que, num primeiro momento, os textos de Quinault foram criticados pelos "antigos" da "Querela dos Antigos e Modernos", mas pouco tempo depois sua obra se tornou o paradigma do bom libreto. E Raguenet concorda com essa visão, confirmando-a através de seus elogios ao libretista francês, os quais são seguidos por uma dura crítica à estrutura dos libretos italianos.

O segundo elemento apontado por Raguenet na sua comparação diz respeito ao uso de um tipo de voz: o baixo (basse-contre), com sua majestade, que seria mais adequado a determinados personagens. Novamente aqui o autor evidencia, através do uso das vozes, o quão diferentes são as tradiçôes. Porque se neste momento Raguenet elogia a voz do baixo francês e a variedade da combinação com dois sopranos, mais adiante lembra que os castrati têm grande versatilidade e ca- 
pacidade de atuação, tanto em papéis femininos como masculinos.

Outro elemento louvado nas óperas francesas, mas ausente da estrutura do espetáculo italiano, são os chamados divertissements, incluindo os vários números musicais: as entrées de balés, os coros, as grandes cenas de tempestade, de sono, etc., tão características da tragédie lyrique ${ }^{23}$. Aqui é o momento em que se torna mais clara a distinção entre os espetáculos italianos e franceses. Já no final do século XVII, inicia-se na Itália uma tentativa de "reforma" dos libretos, buscando uma maior unidade de ação associada à pureza do gênero dramático. Para tanto, foram excluídos os personagens cômicos das ações sérias (o que já acontecia na ópera francesa) e houve um direcionamento para a estruturação da ópera com a alternância entre recitativos e árias ${ }^{24}$. Coros e outros elementos musicais tendem a desaparecer e as árias tornam-se o centro musical das óperas. No caso francês, existe uma riqueza muito maior dos números musicais, o que vai ser constantemente lembrado por outras "reformas" do século XVIII.

Mas, interessado por elementos próprios da execução musical, Raguenet menciona igualmente as diferenças dos instrumentos, da instrumentação das peças, da maneira de tocar e de cantar, com os resultados peculiares a cada tradição. Ao mencionar as árias italianas, aponta seu caráter ousado, o uso das dissonâncias, a desobediência das regras, ao contrário dos franceses que buscavam, através da imitação do modelo, a perfeição da forma. Aqui entra em jogo a discussão do "caráter" francês e do italiano, invocada para esclarecer as diferenças mútuas. E também será discutido o "caráter" de cada língua e seus sons. Esta é uma preocupação que permeia boa parte do discurso sobre música vocal, pois explicita a busca de uma relação quase primordial entre o som da língua, a música e o gosto de cada povo. Além disso, o autor também procura discutir qual a relação mais adequada entre o sentido das palavras e a música instrumental.

Podemos, do mesmo modo, perceber em Raguenet a preocupação com o desempenho das vozes, com a expressividade dos cantores e até mesmo com questões relativas à duração das carreiras. Ora, tudo isso escapa dos interesses tradicionais sobre a ópera, revelando que o autor assumia o espetáculo em seu conjunto e permitia-se dissertar sobre
23. Para detalhes dessas cenas, cf. WOOD (19811982).

24. Certamente a questão da estrutura da ópera italiana do final do século XVII e início do XVIII é toda mais complexa. Para mais detalhes, cf., entre outros, FREEMAN (1968); FABBRI (1990) e GALLARATI (1984). 
25. Para mais detalhes, cf. KLAPER (2005); SCOTTI; KLAPER (2005) e MURATA (1995). ele. Ao apontar as qualidades do vestuário, dos dançarinos, das encenações, da maravilha dos cenários e das máquinas - elementos da ópsis - Raguenet toca em um ponto constantemente esquecido ou menosprezado pelos autores, revelando aqui seu encantamento pelo conjunto do espetáculo.

A maneira um tanto abrupta com que o autor encerra o livro confirma a sensação de um texto relativamente descosturado, aparentemente o fruto irrefletido de uma experiência avassaladora. Podemos, contudo, perguntar-nos o quanto Raguenet estava ciente das diversas polêmicas em torno da ópera (italiana e francesa) na França e de que maneira se posicionou com relação a elas. Uma primeira pergunta seria: o quanto se conhecia de música italiana na França?

A origem italiana da ópera francesa, especialmente através da presença de Lully, italiano de nascimento, é constantemente lembrada, mas, de certo modo, obscurece apresentações anteriores do repertório italiano. Seria possível traçar diversas linhagens da presença italiana na França; mais diretamente interessam aqui as apresentações que trouxeram exemplos de espetáculos totalmente musicados. John S. Powell lembra-nos da presença da commedia dell'arte e das pastorais italianas com música desde a segunda metade do século XVI (POWELL, 2000 , p. 163-170). Menciona igualmente a presença da família Caccini, de dezembro de 1604 a abril de 1605, apresentando peças do repertório italiano mais "moderno". Mas certamente o episódio mais importante é a chegada das óperas italianas em Paris a partir de fevereiro de 1645, quando são apresentadas obras de Marco Marazzoli, Francesco Sacrati (dezembro do mesmo ano), Francesco Cavalli (fevereiro de 1646), Luigi Rossi (março de 1647), Carlo Caproli (abril de 1654), novamente Cavalli em novembro de 1660, em fevereiro de 1662 e também a apresentação de uma obra de Lorenzani em setembro de $1681^{25}$. A partir desse confronto direto com o repertório italiano, ainda que algumas óperas tivessem sido adaptadas ou mesmo compostas para os palcos parisienses, os franceses passam a ter matéria concreta para tratar em suas reflexões sobre a ópera.

Desse primeiro embate nasce um importante texto, cujo objetivo é não apenas comentar alguns "defeitos" das óperas italianas, mas sobretudo o de estabelecer os parâmetros para um espetáculo com música em francês. Trata-se da carta de 
Pierre Perrin, datada de 30 de abril de 1659, ao Senhor della Rovere (PERRIN, 1981). Catherine Kintzler insiste na importância deste texto, classificando-o como a primeira tentativa de uma sistematização poética para a ópera em francês (KINTZLER, 1986, p. 74). Interessa-nos aqui também ressaltar que é uma reflexão nascida da comparação com o espetáculo italiano, promovendo as virtudes próprias de um espetáculo em francês. Para além da ênfase no que seria propriamente francês, despontam, como já se disse, a referência à Itália e a necessidade de ultrapassar o modelo. Ora, a origem italiana da ópera francesa é algo que, apesar de ser claramente percebido, por certo incomodava os franceses, e os argumentos de Raguenet a favor dos italianos torna a questão ainda mais explícita.

É relativamente recente o interesse em encontrar outros elementos de música italiana presentes na cultura francesa. $\mathrm{O}$ artigo de E. T. Corp, sobre o exílio dos Stuart na França e a presença dos músicos italianos vindos de Londres revela uma faceta pouco explorada da vida musical francesa, neste caso em Saint-Germain en Laye (CORP, 1995), justamente nos anos imediatamente anteriores e posteriores à publicação do texto de Raguenet. Do mesmo modo, um artigo de Julie Anne Sadie sobre o fascínio dos franceses com a música italiana revela mais detalhes sobre a difusão das sonatas de Corelli pela França e sua repercussão em compositores como Elisabeth Jacquet de La Guerre e François Couperin, entre outros (SADIE, 1998). Além disso, a presença de árias e lamentos italianos (cantados em língua italiana) nas comédies-ballets de Lully e em obras de outros compositores, indica uma presença constante de elementos da recente tradição italiana de ópera no mundo dos espetáculos franceses ${ }^{26}$. Não queremos com isso afirmar que Raguenet conhecia, por uma ou outra razão, profundamente o que ocorria na França (apesar de, mais tarde, citar, na resposta a Le Cerf de La Viéville, as obras de Corelli); novamente, o que importa, é mostrar que a música italiana era suficientemente conhecida e reconhecida e podia ou não ser encarada como a matriz de parte da produção francesa. A contribuição de Raguenet é aquecer o debate, ao revelar o incrível prazer proporcionado por uma experiência direta com a mais nova música italiana, que ainda não havia
26. Para outros aspectos da presença italiana, cf. ROSOW (2010) e NESTOLA (2006). 
marcado forte presença na França, o que o levou a criticar diversos aspectos da música francesa.

Podemos, assim, ver uma grande dificuldade, por parte dos franceses, com relação à incômoda origem italiana da tragédie lyrique (e também de seu principal criador, Lully) e a necessidade de buscar elementos constitutivos que separassem a ópera francesa da italiana. Em certa medida, a carta de Perrin já estabelece o caminho a ser trilhado; contudo, a comparação com a Itália surge também em outros textos, com vocações variadas. O livro de Ménestrier, Des Representations en Musique Anciennes et Modernes (1681), procura estabelecer as origens das representaçôes teatrais com música, discorrendo sobre o uso da música e iniciando sua história na música "dos hebreus", passando pelos gregos, pelos cristãos, pelos chineses. Discute, como tantos outros, os poderes da música dos gregos para finalmente começar a tratar do retorno da música representativa na Itália e, posteriormente, na França. Interessa-nos desde logo a afirmação de que "cada nação tem seu caráter para o canto e para a música, como para a maior parte das outras coisas, que dependem da diferença de gênio, de usos e de costumes" (MÉNESTRIER,1681, p. 107). O livro não tem apenas um caráter "histórico", já que também examina as partes constitutivas do espetáculo, as necessidades de adaptação para a música e, "como as peças de teatro compostas em música são feitas mais para o prazer e divertimento do que para a instrução" (Idem, p. 170), o autor assume o maravilhoso como elemento essencial para a ópera. Mas o mais interessante, no que respeita à relação com a Itália, é a extensa e minuciosa descrição do Orfeo de Luigi Rossi, representado na França em 1647 (Idem, p. 195-207). O autor reconhece que o ponto de inflexão para as representaçóes em música no país veio da Itália, com adaptaçóes, o que não parece constituir um problema.

Já em Saint-Evremond, no seu conhecido e constantemente citado texto sobre a ópera, a proposta é de uma crítica geral aos espetáculos, mas também a de falar da diferença "entre a maneira de cantar dos italianos e a dos franceses" (SAINT-EVREMOND, 1684, p. 78). Às severas críticas à presença da música e do maravilhoso, é acrescentada uma pequena comparação entre os espetáculos dos dois países. Para começar, existe uma aproximação entre franceses e italianos, já que para o autor "os gregos faziam belas tragédias, em que cantavam 
algo, os italianos e franceses fazem más [vilaines] tragédias, em que eles cantam tudo"(Idem, p. 90). Assim, ambas são defeituosas e na verdade cometeram um pecado original, o de propor espetáculos inteiramente cantados. Mas Saint-Evremond lembra igualmente a pouca estima que os italianos têm pelos espetáculos franceses e o desgosto [dégoust] provocado pela ópera italiana nos franceses. Italianos não compreendem o encadeamento de danças e de música dos franceses e sua relação com o tema das óperas; franceses não gostam do uso de instrumentos das óperas venezianas nem dos longos e tediosos recitativos. É curioso notar que o autor aponta elementos constitutivos da ópera francesa (os divertissements) e considera-os como defeitos, justamente o oposto do que fará Raguenet, por outros motivos. Há, na verdade, em Saint-Evremond, uma velada crítica aos libretos de Quinault e à própria estrutura da ação, pois, segundo o autor, "pensamos em ir a uma representação, onde nada se representa; queremos ver uma comédia, onde não se encontra nenhum espírito de comédia" (Idem, p. 99) ${ }^{27}$.

Contudo, uma vantagem dos franceses estaria na execução ou no canto em si. Para Saint-Evremond, os italianos são falsos na expressão pois não conhecem com justeza os graus das paixões. Na verdade, eles seriam exagerados para o gosto francês e, citando uma provável afirmação de Luigi Rossi, o autor diz que "para tornar uma música agradável, seriam necessárias árias italianas na boca dos franceses" (Idem, p.106). Também a maneira de tocar os instrumentos dos franceses teria agradado ao compositor italiano. O texto de Saint-Evremond, que circulou pela Europa e foi usado, por exemplo, por Barthold Feind em sua crítica à ópera na Alemanha (FEIND, 1708), também constitui aqui uma importante relação com Raguenet. Este havia preparado a edição de uma seleção de obras de Saint-Evremont, publicada por Barbin em $1700^{28}$. Fica claro que de um modo ou de outro Raguenet conhecia as críticas de Saint-Evremond à ópera. Com isso, o Paralelo deixa de ser apenas o relato de um amador da ópera italiana e passa a ser também um importante instrumento numa longa polêmica francesa.

A pequena obra de Raguenet despertou a fúria de outro autor: Lecerf de La Viéville (1674-1707) publica em 1705
27. Por comédia entenda-se ação teatral.

28. Nouvelles Euvres meslées de Monsieur de Saint-Evremont. Paris: Claude Barbin, 1700. O prefácio não é assinado por Raguenet, mas ele sempre foi mencionado como seu autor. Afirmam os comentadores que os textos publicados no livro não são todos de autoria de Saint-Evremond, seguindo uma prática de publicação de falsas obras. Cf. HAYWARD (1972, p.xviii). 
sua resposta às ideias contidas no Paralelo (LECERF DE LA VIÉVILLE, 1972). A ópera é, mais uma vez, trazida para o domínio das polêmicas: insere-se numa reflexão específica sobre música, ópera e teatro na França, evocando a querela dos antigos e dos modernos, as críticas morais aos espetáculos, o debate sobre a relação texto-música (Cf. BROOKS, 1994), as críticas contra o absurdo e o monstruoso e, finalmente, as inevitáveis comparações com a Itália. Em princípio, ou pelo menos aparentemente, Raguenet estava fora dessas discussóes, mas ele é arrastado para dentro de um grande processo de ataques e defesas. $\mathrm{O}$ ataque de Le Cerf de la Viéville pretende ser minucioso e comporta uma argumentação pesada, muito distante daquela apresentada pelo livro de Raguenet. Existe uma defesa do paralelo (RAGUENET, 1705), que novamente é comentado por Lecerf de La Viéville (1706). O conjunto da polêmica soa como uma reação desproporcional à proposta de Raguenet, lembrando mais uma rixa pessoal do que o debate de questôes relacionadas à música e à ópera. Pelo que se depreende do conjunto dos textos, La Viéville não conhecia muito bem a música italiana e, por isso, as invectivas contra a ópera italiana soam um tanto superficiais. Há uma discussão sobre o caráter das línguas francesa e italiana e suas repercussões na música; La Viéville invoca até mesmo o japonês e o árabe, tentando mostrar as desvantagens da língua italiana. Mas é ao falar de música italiana que La Viéville deixa aparente suas dificuldades: ele cita Corelli como autor de óperas, argumento que é imediatamente revidado por Raguenet. E este continua sua crítica por toda a Defesa: a linguagem de La Viéville é equivocada, falar sobre o que não se conhece é um dos pecados mais graves, etc. Na Defesa fica igualmente patente o posicionamento dos dois autores com relação à Querela dos Antigos e dos Modernos, assim como o conhecimento das obras de Saint-Evremond que tratam da ópera. Ou seja, mesmo que a proposta inicial do livro de Raguenet pudesse aparecer como um retrato "imparcial" da situação da música na França e na Itália, a leitura que ele sofreu indicava um ambiente belicoso. As críticas nos jornais parisienses da época também revelam algum interesse do público em torno do tema debatido ${ }^{29}$.

A posteridade também usará o texto de Raguenet. No tomo III, na 4a parte das Querelles Litéraires (1761) do abade 
Irail, na tentativa de construir a origem de outra querela, desta vez a dos Bufōes, o autor escreve:

Antes que os bufóes viessem a Paris, estávamos divididos sobre a música italiana: ela semeou a divisão em 1704; o autor do Paralelo dos Italianos e dos franceses, no que concerne à música e às óperas já havia lançado o pomo da discórdia. Esta obra do abade Raguenet, fruto de suas viagens na Itália, era um elogio ultrajado da música dessa nação, um tributo de reconhecimento de todas as honras que ele lá havia recebido. Os conservadores de Roma o haviam condecorado com o título de cidadão romano (IRAIL, t. III, p. 90-91).

Ao ligar a preferência de Raguenet pela Itália às honrarias recebidas, o autor já toma o partido da música francesa e de La Viéville, mas o que nos interessa mais neste momento é destacar como, para alguns, Raguenet estaria na origem da Querela dos Bufóes.

Não nos cabe aqui discorrer sobre esta disputa que tantos escritos gerou ${ }^{30}$ e sim, apenas apontar algo curioso. Em 1953, já no final da polêmica, o texto de Raguenet é republicado postumamente, desta vez com o título $A$ paz da ópera ou paralelo imparcial da música francesa e da música italiana (RAGUENET, 1973). A questão da imparcialidade assombra o pequeno livro de Raguenet desde sua publicação. O parecer de Fontenelle dizia que o livro seria muito "agradável ao público, desde que ele fosse capaz de "equidade". Tal parecer será constantemente citado pelos autores que se debruçaram sobre o texto. Ora, como já vimos, desde muito cedo o livro foi lido como uma provocação e certamente Raguenet não era nem ingênuo nem ignorante com relação às implicações do que escreveu. E a nova publicação de 1753 não é uma mera reedição do texto com um novo título, mas sim de um texto com variantes significativas. A começar pelo título, a nova versão parece responder a La Guerre de l'Opéra, de Jacques Cazotte, publicado anonimamente em 1753 (CAZOTTE, 1753). O texto de Cazotte aparece como uma tentativa "neutra" de identificar os dois lados da polêmica, o francês e o italiano, inclusive com a contabilização dos "mortos e feridos" (Idem, p. 24). Mas certamente o novo título do livro de Raguenet assume um caráter conciliatório e pacificador da "guerra". O próprio editor anônimo da publicação diz tratar-se de um ex- 
31. O texto aparece dividido em três cartas (IX, XII e XV). Cf. MARPURG (1760, I, p. 65-71, 89-94 e 113-118).

32. Para um aprofundamento do debate sobre o gosto em música no mundo de língua alemã, cf. PAOLIELLO (2011). trato da obra original, considerada por ele de "estilo difuso" e "pouco correto", necessitando assim de uma retificação e de notas, que tornariam o texto mais neutro ou equânime. Nelas, o editor faz uma espécie de defesa da música francesa, citando porém compositores que despontaram depois da publicação original da obra de Raguenet. As adiçóes ao texto iniciam na página 35, também com consideraçôes sobre a ópera e a música francesas, como que completando o que Raguenet já havia dito sobre elas, indicando outros caminhos para aperfeiçoar a ópera francesa.

Outro fator relevante para a compreensão da importância do texto de Raguenet é sua difusão em inglês e em alemão. $\mathrm{Na}$ Inglaterra, o texto foi publicado juntamente com um discurso sobre a maneira de melhorar a ópera no país (RAGUENET, 1946). Se pensarmos que, na Inglaterra do início do século XVIII, a ópera italiana já se tornava um espetáculo de grande difusão, ao mesmo tempo conhece-se a desconfiança com que foi recebida em determinados meios, especialmente nas publicações de Joseph Addison e Richard Steele (Cf. NEUFELDT, 2004 e FAUST, 2007). Percebe-se, na publicação inglesa, a tentativa de usar o texto de Raguenet para defender a ópera italiana, mesmo com as críticas que já existiam dentro do próprio texto francês. O discurso que acompanha a tradução faz uma pequena história das apresentaçóes de ópera italiana nos palcos ingleses, com grande ênfase na Camilla de Bononcini, e tem como objetivo principal melhorar esse tipo de espetáculo. Esse uso do livro de Raguenet parece ser uma constante, mesmo nas publicações alemãs.

$\mathrm{Na}$ Alemanha, o texto aparece em duas traduçōes diferentes: no Critica Musica (1722) de Mattheson (2003) e no Kritische Briefe über di Tonkunst de Marpurg ${ }^{31}$. No caso de Mattheson, que apresenta o texto original francês em paralelo com sua tradução comentada, fica claro que o interesse maior está em destacar as qualidades de ambas as tradições no mundo da ópera, com o propósito de encontrar um tipo de espetáculo com música que combinasse as virtudes de cada uma delas. A tarefa certamente não é fácil, mas faz parte daquilo que passou a ser conhecido como gồts réunis ${ }^{32}$. A chegada da ópera nos territórios de língua alemã é uma longa história de adaptações, de usos de tradições diversas, de censura religiosa e política, e também de experimentações. O lugar privilegia- 
do delas foi certamente o Theater am Gänsemarkt de Hamburgo $^{33}$, onde atuaram R. Kaiser, o jovem G. F. Händel e o próprio Mattheson. Para alguns teóricos de língua alemã, as experimentaçôes no domínio da ópera ${ }^{34}$, com a combinação do que seriam os melhores elementos "italianos" e "franceses" do espetáculo teria fundamental importância em direção a um espetáculo "alemão". O texto de Raguenet forneceria então critérios para esta seleção e assumiria um papel de guia para a empreitada. Já em Marpurg, a nova tradução do texto do autor francês aparece dentro de cartas que procuram responder a questôes sobre o gosto dos franceses e dos italianos, mas também como maneira de escolher o melhor. Marpurg já inicia ironicamente seus comentários ao afirmar que "se falasse a partir de meu sentimento, diria que gostaria de ouvir um francês falar sobre a música, mas preferiria ouvir uma música italiana [...]"(MARPURG, 1760, p. 65).

O uso do texto de Raguenet soa como tendencioso, já que Marpurg, pelo menos no que diz respeito à música, prefere a italiana. Restaria então aos franceses apenas falar sobre música. É interessante lembrar também que Marpurg promete publicar a carta de Rousseau sobre a música francesa, que, como se sabe, praticamente destrói qualquer possibilidade de existência de uma boa música na França, segundo os parâmetros do autor de Genebra ${ }^{35}$. Como se vê, na Alemanha o Paralelo é utilizado em uma nova cruzada: se aparentemente o texto é trazido com certa "neutralidade" para o debate sobre música em língua alemã, não é difícil perceber uma predileção pela música italiana, ainda que os franceses apareçam como superiores na construção dos libretos.

Paralelos, comparações e as difíceis relações com a Itália são temas recorrentes nas teorias artísticas francesas. O paralelo de Raguenet tende a consolidar determinadas visões sobre duas tradiçōes distintas de ópera. É uma atitude classificatória, de modo a ordenar a compreensão sobre o mundo. Menestrier já havia tentado definir o "caráter musical" das nações e, segundo a nomenclatura alemã da metade do século XVIII, seriam estabelecidos os diversos estilos nacionais. Já no século XVII, Saint-Evremond mencionava uma citação latina corrente no mundo francês, que será citada por La Viéville e por Raguenet em sua defesa: Hispanus flet, dolet Italus, Germanus boat,
33. Detalhes sobre a ópera em Hamburgo podem ser encontrados em CARPENA (2007) e na bibliografia ali contida.

34. Para uma discussão sobre como a proposta de criação de uma música "alemã" torna-se uma proposta de criação de uma música "universal", cf. SPONHEUER (2002).

35. Ao comentar novas publicações na França em 1754, Marpurg destaca a polêmica em torno da Carta sobre a música francesa de Rousseau e indica Raguenet e Le Cerf de la Viéville como o início da oposição entre as duas partes. Cf. MARPURG (1970, I, p. 146-147).

36. "O espanhol chora, o italiano lamenta, o alemão muge, o flamengo uiva e somente o francês canta". 
Flander ululat, et solus Gallus cantat (SAINT-EVREMOND, 1684 , p. 105$)^{36}$. Variantes são conhecidas, inclusive como anedotas, associando cada nação a um caráter e posteriormente, como se sabe, ao clima, ao gênio, ao gosto e a tantos outros fatores. No mundo da prática musical na França, também há diversos exemplos, tais como as árias italianas nas óperas, ou os turcos, italianos e espanhóis no Burguês Fidalgo de Molière e Lully, ou ainda o Concert des Nations de Couperin, em que as diferenças eram musicalmente representadas.

Mas, como bem se pode ver nas diversas polêmicas francesas em torno da ópera durante o século XVIII, a referência à Itália é constante e difícil. Como vimos, para alguns Raguenet estaria na origem da Querela dos Bufôes; para d Alembert, ao comparar o efeito produzido pelo Paralelo com a Carta sobre a música francesa de Rousseau, o pequeno texto de Raguenet aparece como algo mais moderado. Aliás, em seu La Liberté de la Musique, d'Alembert assume igualmente um tom moderado na polêmica e está mais preocupado em relacionar a música e os costumes e também discutir a inevitável comparação com os italianos: "Há uma espécie de fatalidade, neste século, ligada ao que nos vem da Itália. Todos os presentes, bons ou maus, que ela nos quer dar, são para nós um problema” (D'ALEMBERT, 1759, p. 393).

O autor também compara, mede, pesa as diferenças, critica a ópera em sua essência e reafirma a superioridade da tragédia recitada. Mas com relação aos italianos, escreve:

Rafael não fez dissertações, mas quadros. Em música, nós escrevemos e os italianos executam. As duas naçôes, neste aspecto, são a imagem dos dois arquitetos que se apresentaram aos atenienses para um monumento que a República queria construir. Um falou por um longo tempo e, muito eloquentemente, sobre sua arte; o outro, depois de o ter escutado, pronunciou apenas estas palavras: tudo o que ele disse, eu o farei (D'ALEMBERT, p. 462).

No contexto, isso valeria como um chamado aos franceses para realizar boas obras, pois, ao contrário de Rousseau, d'Alembert acreditava na possibilidade da existência de uma música francesa. Mas a referência à Itália continua sendo complexa, mesmo no século XIX. Delacroix, ao escrever sobre a vida de Poussin, afirma que ele "teria libertado nosso país des- 
sa eterna e frequentemente cega devoção a tudo o que é da Itália”, queixando-se da constante dependência (DELACROIX, 1988, p. 239). A insatisfação dos franceses mascara um outro aspecto das polêmicas e dos embates: se, aparentemente, o mundo teórico italiano, em geral, não deu atenção à ópera francesa, diversos compositores tiveram propostas de reforma da ópera italiana inspirados no modelo francês: N. Jommelli, T. Traetta, C. W. Gluck e até o próprio Mozart em seu Idomeneo. Além, é claro, do modelo de Racine para tantos libretos e também o interesse por Quinault, por parte dos italianos. Novamente, as comparações servem como um repertório das vantagens das duas tradiçóes que poderão ser escolhidas pelos compositores com o intuito de criar espetáculos que atendessem a outros anseios.

O texto de Raguenet em certa medida ultrapassou o que em princípio era uma proposta modesta: comparar duas tradiçôes, mostrar as vantagens de cada uma, na ótica de um escritor que se encantou pela Itália. O autor, já no texto em que tratava dos monumentos de Roma, dizia buscar uma maneira distinta para se aproximar das obras de arte naquela cidade: em primeiro lugar, procurava uma descrição que "pintasse mais ao espírito do que aos olhos", fazendo seu leitor "ver Roma, sem a própria Roma”; em segundo, pretendia deixar de lado as "descriçõos superficiais, em termos vagos e gerais”, entrando no espírito dos artistas; por fim, para atingir seu objetivo, dizia não conhecer nenhum guia ou modelo, já que as descriçóes de Plínio e de outros antigos, mas também dos modernos que seguiram seus passos, não poderiam servir de modelo (RAGUENET, 1765, Préface). Em certo modo, o mesmo ocorreu ao tratar da ópera. A ênfase no espetáculo como um todo, ainda que reconhecesse a importância fundamental do libreto, levando em consideração os cenários, as vestimentas, o caráter das vozes dos cantores e assim por diante, destoava do discurso geral sobre ópera. A preocupação com a actio soa como uma exceção nos tratados e escritos sobre os espetáculos, em geral, e sobre aqueles com música, em particular. Outro exemplo pode ser encontrado no livro de Grimarest (1707), que tinha, contudo, uma proposta mais específica. Ele discorre sobre o recitativo na leitura, na ação pública, na declamação teatral e na ópera. Nesta última, afirma o autor: 
É necessário considerar a música vocal em relação ao músico que a compõe, ao ator que a canta e à pessoa que a escuta. A ciência e o gosto são necessários a quem compõe; quem canta precisa de arte, de ciência e de discernimento; e o que escuta deve ter todas essas partes para julgar acertadamente (GRIMAREST, 1707, p. 198).

A discussão sobre a actio ocorre dentro dos limites da Retórica, e, apesar de normativa e em certo sentido conservadora, também evidencia uma preocupação com a representação. E essa é uma das grandes preocupações de Raguenet. Seríamos tentados a transformar a atitude dele com relação aos espetáculos com música numa espécie de poética da ópera, mas isso estaria fora do escopo de seu pequeno livro. Alguns autores classificaram Raguenet de "sensualista", ou como alguém que apresenta a "emoção de um diletante", em certo sentido minimizando a importância do livro. Discussões posteriores que tentaram de algum modo criar preceptivas para a ópera deixaram de lado todos os elementos que fascinaram Raguenet $\mathrm{e}$ somente uma teorização muito posterior, criando raízes metodológicas para a pesquisa sobre ópera, abriu caminhos para uma abordagem mais ampla do espetáculo como um todo, e não somente da música e do libreto.

\section{REFERÊNCIAS.}

D’ALEMBERT, Jean Le Rond. De la liberté de la musique. In: Mélanges de littérature, d"histoire, et de philosophie, Nouvelle édition, tome 4. Amsterdã: Zacharie Chatelain, p. 379-462, 1759.

D'ALEMBERT, Jean Le Rond; DIDEROT, D. (Org.) Encyclopédie, ou dictionnaire raisonné des sciences, des arts et des métiers. Paris: Chez Briasson, David l'ainé, Le Breton, Durand, 1751-1772. Disponível em <http://portail.atilf.fr/ encyclopedie/>. Acesso em: 30/12/2012.

ARISTÓTELES. Poética. Tradução, Prefácio, Introdução, Comentários e Apêndices de Eudoro de Souza. Lisboa: Imprensa Nacional - Casa da Moeda, FCSH da Universidade Nova de Lisboa, 1986. 
ARISTÓTELES. Poética de Aristóteles. Ed. trilíngüe de V. García Yebra, Madri: Gredos, 1992.

BARTHELEMY, Maurice. Métamorphoses de l'Opéra français au siècle des Lumières. Arles: Actes Sud, 1990.

BROOKS, William. Mistrust and Misconception: Music and Literature in Seventeenth and Eighteenth-Century France. In: Acta Musicologica, Basileia, v. 66, n. 1, p. 22-30, Jan.-Jun. 1994.

BROOKS, William; NORMAN, Buford; ZARUCCHI, Jeanne, M. Philippe Quinault - Alceste. Suivi de La Querelle d'Alceste. Anciens et modernes avant 1680. Paris: Droz, 1994.

BROSSARD, Sébastien de. Dictionnaire de Musique contenant une explication des Termes Grecs, Latins, Italiens et Français, les plus usitez dans la Musique. $3^{a}$ edição. Amsterdã: E. Roger, [1708].

CARPENA, Lucia B. Caracterização e uso da flauta doce nas operas de Reinhard Keiser (1674-1739). 530 páginas. Tese (Doutorado em Música), UNICAMP, Campinas, 2007.

CAZOTTE, Jacques. La Guerre de l'Opéra. Lettre écrite à une dame en province, par quelqu'un qui n'est di d'un Coin, ni de l'autre. S.n.t., 1753. Disponível em <http://catalogue. bnf.fr/ark:/12148/cb33410021n>. Acesso em: 30/11/2012.

CLÉMENT, Jean-Marie Bernard. Dumeni. In: Bibliothèque des Théâtres. Dictionnaire dramatique, t. III, Paris, chez la Veuve Duchesne, p. 171, 1784.

CORP, Edward T. The Exiled Court of James II and James III: A Centre of Italian Music in France, 1689-1712. In: Journal of the Royal Music Association, Londres, v. 120, n. 2, p. 216-231, 1995.

CYR, Mary. On performing 18th-Century Haute-Contre Roles. In: The Musical Times, East Sussex, v. 118, n. 1610, p. 291-295, Abr. 1977.

DELACROIX, Eugène. Le Poussin. In: Ecrits sur l'Art, Paris, Librairie Séguier, p. 209-255, 1988. 
Dictionnaire de l'Académie française. Paris: Jean-Baptiste Coignard, 1694.

FABIANO, Andrea (Org.). La "Querelle des Bouffons" dans la vie culturelle française du XVIII siècle. Paris: CNRS, 2005.

FABBRI, Paolo. Il Secolo Cantante. Per una storia del libretto d'opera nel Seicento. Bolonha: Il Mulino, 1990.

FADER, Don. The Honnête homme as Music Critic: Taste, Rhetoric, and Politesse in the 17th-Century French Reception of Italian Music. In: Journal of Musicology, Berkeley (CA), v. 20, n. 1, p. 3-44, 2003.

FAUST, Veronica. 'Music has learn'd the discords of the state': The Cultural Politics of British Opposition to Italian Opera, 1706-1711. In: The Haverford Journal, Haverford (PA), v. 3, n. 1, p. 4-39, Abr. 2007.

FEIND, Barthold. Gedancken von der Opera. S.l.: Honrich Brummer, 1708.

FRAMERY, Nicolas Etienne; GINGUENÉ, Pierre Louis. Encyclopédie Méthodique publiée par MM. Framery et Ginguené. Paris: chez Panckoucke, 1791.

FRAMERY, Nicolas Etienne; GINGUENÉ, Pierre Louis; DE MOMIGNY, Jérôme-Joseph. Encyclopédie méthodique. Musique, publiée par MM. Framery, Ginguené et De Momigny. Paris: chez $\mathrm{M}^{\mathrm{me}}$. Veuve Agasse, 1818.

FRANCHI, Saverio. Drammaturgia Romana. Repertorio Bibliografico Cronologico dei Testi drammatici pubblicati a Roma e nel Lazio, secolo XVII. Roma: Edizioni di Storia e Letteratura, 1988.

FREEMAN, Robert. Apostolo Zeno's Reform of the Libretto. In: Journal of the American Musicological Society, Berkeley (CA), vol. 21, n. 3, p. 321-341, Autumn, 1968.

FUBINI, Enrico. Gli Enciclopedisti e la musica - nuova edizione. Turim: Piccola Biblioteca Einaudi, 1991. 
FUMAROLI, Marc. Les abeilles et les araignées. In: La Querelle des Anciens et des Modernes - XVII ${ }^{e}$-XVIII ${ }^{e}$ siècles. Paris: Gallimard, 2001.

GALLARATI, Paolo. Musica e Maschera. Il libretto italiano del Settecento. Turim: EDT/Musica, 1984.

GRIMAREST, Jean-Léonor Le Gallois de. Traité du récitatif: dans la lecture, dans l'action publique, dans la déclamation, et dans le chant: avec un traité des accens, de la quantité, \& de la ponctuation. Paris: chez Jaques Le Fevre et Pierre Ribou, 1707.

HAYWARD, John Davy (Org.). The Letters of Saint-Evremond. Nova York: Benjamin Blom, 1972.

HORÁCIO. De Arte Poetica Liber. Testo e commento di A. Rostagni. Turim: Chantore, [19--].

IRAIL, Simon Augustin. Querelles Littéraires ou Mémoires pour servir à l'histoire des Révolutions de la République des Lettres, depuis Homère jusqu'à nos jours. Paris: Chez Durand, 1761.

KINTZLER, Catherine. De la Pastorale à la Tragédie lyrique: quelques éléments d'un système poétique. In: Revue de Musicologie, Paris, v. 72, n.1, p. 67-96, 1986.

KINTZLER, Catherine. Poétique de l'opéra: De Corneille à Rousseau. Paris: Minerve, 2006.

KLAPER, Michael. Vom Drama per musica zur Comédie em musique: Die Pariser Adaptation der Oper Xerse (Minato/Cavalli). In: Acta musicologica, Basileia, v. 77, p. 229-256, 2005.

LAUNAY, Denise (Org.). La Querelle des Bouffons. Textes de pamphlets avec introduction, commentaires et index. Genebra: Minkoff, 1973.

LE CERF DE LA VIÉVILLE DE FRESNEUSE, Jean.-Laurent L'art de décrier ce qu'on n'entend point, ou Le médecin musicien: exposition de la mauvaise foi d'un extrait du Jour- 
nal de Paris. Bruxelas : Chez François Foppens, au Saint-Esprit, 1706.

LE CERF DE LA VIÉVILLE DE FRESNEUSE, Jean.-Laurent. Comparaison de la musique italienne et de la musique française, où, en examinant en détail les avantages des spectacles, et le mérite des compositions des deux nations, on montre quelles sont les vrayes beautéz de la musique par J. L. Lecerf de la Viéville de Fresneuse. Bruxelas: F. Foppens 1704; 1705. Genebra: Minkoff Reprint, 1972.

MARPURG, Friedrich Wilhelm. Kritische Briefe über die Tonkust, mit kleinen Clavierstücken und Singoden, Berlim: F. W. Birnstiel, 1760.

MARPURG, Friedrich Wilhelm, Historisch-kritische Beyträge zur Aufnahme der Musik [1754-1778], Hildesheim: Olms Verlag, 1970.

MATTHESON, Johann. Der musicalischen Parallele [ed. bilíngue alemão-francês], Erster Abriss., August 1722. In MATTHESON, J., Critica Musica [1722-1725], Laaber: Laaber-Verlag, 2003.

Mémoires pour l'Histoire des Sciences \& des beaux Arts. Trevoux: Chez Estienne Ganeau, Ago. 1702.

MÉNESTRIER, Claude.-François. Des Representations en Musique Anciennes et Modernes. Paris: Renéee Guignard, 1681.

MURATA, Margaret. Why the First Opera Given in Paris Wasn't Roman. In: Cambridge Opera Journal, Cambridge, v. 7, n. 2., p. 87-105, Jul. 1995.

NESTOLA, Barbara. Les sources littéraires des airs de cour en italien. In: DUROSOIR, Georgie (Org.). Poésie, Musique et Société. L'air de cour en France au XVIII siècle. Bruxelas: Mardaga, p. 109-121, 2006.

NEUFELDT, Tim. Italian Pastoral Opera and Pastoral Politics in England, 1705-1712. In: Discourses in Music, v. 5, n. 
2, 2004. Disponível em <http://www.discourses.ca/v5n2a2. html>. Acesso em: 30/11/2012.

PAOLIELLO, Noara de O. Os Concertouvertures de Georg Philipp Telemann: um estudo dos Gostos Reunidos segundo as preceptivas setecentistas de Estilo e Gosto. 171 pág. Dissertação (Mestrado em Música), Universidade de São Paulo, São Paulo, 2011 .

PERRAULT, Charles. Parallèle des Anciens et des Modernes. Paris: chez Jean Baptiste Coignard, 1688-1697.

PERRIN, Pierre. Lettre écrite à Monsieur l'archevêque de Turin. In: OSTHOFF, Wolfgang. ET ALLI. Quellentexte zur Konzeption der europäischen Oper im 17. Jahrhundert. Kassel, Basileia, Londres: Bärenreiter, p. 105-111, 1981.

POWELL, John S. Music and Theatre in France 1600-1680. Oxford: Oxford University Press, p. 163-170, 2000.

RAGUENET, François. A Comparison Between the French and Italian Musick and Operas. Translated from the French; With some Remarks to which is added A Critical Discourse upon Opera's in England, and a Means proposed for their Improvement. Londres: Printed for William Lewis, 1709. In: The Musical Quarterly, Oxford, v. 32, n. 3, p. 411-436, Jul. 1946.

RAGUENET, François. Défense du parallèle des italiens et des français, en ce qui regarde la musique \& les Opéra. Paris: Chez la veuve de Claude Barbin, 1705.

RAGUENET, François. Observations nouvelles sur les ouvrages de peinture, de sculpture et d'architecture qui se voyent à Rome, \& aux environs: pour servir de suite aux Mémoires des voyages et recherches du comte de $\mathrm{B}^{* * *}$ à Rome par M. de Raguenet. Londres: Moyse Chastel, 1765.

RAGUENET, François. La Paix de L'Opéra, ou Parallèle impartial de la Musique Française et de la Musique italienne. Amsterdã, 1753. In: LAUNAY, Denise (Org.). La Querelle des Bouffons. Textes de pamphlets avec introduction, commentaires et index. V. 1. Genebra: Minkoff, p. 513-552, 1973. 
RAGUENET, François. Paralèle [sic] des Italiens et des François en ce qui regarde la musique et les opéra. Paris: Jean Moreau, 1702.

ROUSSEAU, Jean-Jacques. Haute Contre. In: ROUSSEAU, Jean-Jacques. Dictionnaire de Musique. In: Euvres Complètes de J.- J. Rousseau. Paris: Dalibon, p. 437, 1826.

ROSOW, Lois The Descending Minor Tetrachord in France: an Emblem Expanded. In: THOMPSON, Shirley (Org.) New Perspectives on Marc-Antoine Charpentier. Surrey: Ashgate, p. 63-88, 2010.

SADIE, Julie Anne, Devils and Archangels: The French Fascination with ultramontane music. In: MEMED, Orhan. (Org.). François Couperin - Nouveaux Regards. Actes des Rencontres de Villecroze, 4 au 7 octobre 1995, sous la direction d'Huguette Dreyfus, Académie Musicale de Villecroze. Paris: Klincksieck, p. 149-162, 1998.

SAINT-EVREMOND, Charles de M. de Saint-Denis, Seigneur de. Sur les Opera. In: Euvres Meslées, t. XI, Paris: C. Barbin, p. 77-119, 1684.

SCOTT, Gregory. The Poetics of Performance: The Necessity of Spectacle, Music and Dance in Aristotelian Tragedy. In: KEMAL, Salim; GASKELL, Ivan (Org.). Performance and Authenticity in the Arts. Cambridge: Cambridge University Press, p. 15-48, 2000.

SCOTTI, Alba; KLAPER, Michael. Die italienische Oper zwischen Rom und Paris: L'Orfeo (1647) von Francesco Buti und Luigi Rossi. In: Archiv von Musikwissentchaft, Stuttgart, Jahrgang 62, Heft 4, p. 251-266, 2005.

SPONHEUER, B. Reconstructing Ideal Types of the "German" in Music. In: APPELGATE, C., POTTER, P. (Org.). Music \& German National Identity. Chicago e Londres: University of Chicago Press, p. 36-58, 2002.

STORER, Mary Elizabeth. Abbé François Raguenet: Deist, Historian, Music and Art Critic. In: The Romanic Review, Nova York, n. 36, p. 283-296, Dez. 1945. 
TOMÁS, Lia. Música e Filosofia - estética musical. São Paulo: Irmãos Vitale, 2004.

WOOD, Caroline. Orchestra and Spectacle in the tragédie en musique 1673-1715: oracle, sommeil and tempête. In: Proceedings of the Royal Musical Association, Oxford, v. 108, p. 25-46, 1981-1982.

ZASLAW, Neal. The enigma of the Haute-Contre. In The Musical Times, East Sussex, v. 115, n. 1581, p. 939-941, Nov. 1974.

ZASLAW, Neal. When is an Orchestra not an Orchestra? In: Early Music, Oxford, v. 16, n. 4, p. 483-495, Nov. 1988. 


\section{PARALELO ENTRE ITALIANOS E FRANCESES NO QUE CONCERNE À MÚSICA E ÀS \\ ÓPERAS.}

PARIS, JEAN MOREAU, 1702

François Raguenet

Aprovação do Sr. de Fontenelle ${ }^{1}$, da Academia Francesa.

$\mathrm{Li}$, por ordem do Sr. Chanceler, o presente manuscrito e acredito que a impressão será muito agradável ao público, desde que ele seja capaz de equidade. Paris, 25 de janeiro de 1702.

Privilégio do Rei. [...]

Paralelo entre Italianos e Franceses no que concerne à Música e à Ópera.

Há numerosas coisas em que os franceses superam os italianos, no que concerne à música; e há numerosas outras, em que os italianos têm vantagem sobre os franceses, de tal modo que eu não poderia resolver-me a examiná-las em detalhe, se não estivesse persuadido de que é absolutamente necessário entrar na questão para fazer um paralelo justo e proceder a um julgamento exato de umas e de outras.

As óperas são as maiores obras de música que temos o costume de ouvir: são comuns aos italianos e franceses; é nelas que uns e outros mais se esforçaram para fazer brilhar seu gênio. Eis por que será sobre essa espécie de obras que farei correr principalmente o paralelo. Mas há muitas coisas que devem ser especificadas para tal fim: a língua italiana e a língua francesa, das quais uma pode ser mais favorável do que a outra para a música; a composição das peças de teatro que os músicos póem em música; a qualidade dos atores; a dos instrumentistas; as diferentes espécies de voz; o recitativo; as árias; as sinfonias; os coros, as danças, as máquinas, as decorações e todas as outras coisas que entram na composição das óperas e que contribuem à perfeição do espetáculo. Pois é
1. Bernard de Fontenelle (1657-1757), literato, filósofo, grande difusor das idéias de seu tempo. Foi membro de diversas academias científicas e literárias da França e de outros países. Tornouse membro da Académie Française em 1691. 
2. Philippe Quinault (1635-1688), poeta, dramaturgo e libretista francês, colaborou com Jean-Baptiste Lully em treze obras. As obras de Quinault são constantemente citadas como modelo a ser seguido, especialmente por autores italianos que desejavam maior unidade nas óperas italianas. Os libretos podem ser lidos na edição moderna de norman (1999).

3. Era comum, na ópera italiana, a inclusão de árias pertencentes a outras óperas. Não se tratava de pastiches, mas das próprias óperas, que eram adaptadas segundo as necessidades de cada apresentação, as vontades dos cantores, etc. Era uma característica muito criticada por numerosos teóricos, já que se rompia qualquer idéia de unidade da obra e de respeito pela estrutura dos libretos.

4. Basse-contre é propriamente a voz

de baixo. Sébastien de BROSSARD (1705, p. 7), preciso examinar todas as coisas em particular para bem julgar aquelas em que os italianos ou os franceses se sobressaem.

Nossas peças de teatro, sobre as quais os músicos trabalham, estão muito acima das dos italianos: são peças regulares e contínuas [suivies]. Se apenas declamássemos as palavras, sem cantá-las, elas agradariam tanto quanto outras peças de teatro que não são cantadas. Nada é mais espiritual do que os diálogos que lá se encontram; nelas, os deuses falam com toda a dignidade de seu caráter; os reis, com toda a majestade de sua condição; os pastores e pastoras, com o terno gracejo que lhes convém. Amor, ciúmes, furor e outras paixões são tratadas com arte e delicadeza infinitas e há poucas tragédias ou comédias mais belas do que a maior parte das óperas que Quinault ${ }^{2}$ fez.

As óperas dos italianos, ao contrário, são rapsódias lastimáveis, sem ligação, sem seqüência [suite], sem intriga. Suas peças são mais propriamente esboços muito fracos e escassos: todas as cenas são compostas de alguns diálogos ou monólogos triviais, no fim dos quais eles encaixam alguma de suas mais belas árias, a qual finaliza a cena. As árias são muito freqüentemente árias soltas, que de modo algum pertencem ao corpo da peça e que foram feitas por outros poetas, separadamente ou na seqüência de alguma outra obra ${ }^{3}$. Quando o empresário de ópera juntou sua trupe em alguma cidade, ele escolhe por tema de sua ópera a peça que lhe agrada, como Camila, Temistocles, Xerxes, etc. Mas essa peça é apenas, como acabo de dizer, um esboço, que ele recheia com as mais belas árias que os músicos de sua trupe conhecem. Pois essas belas árias são selas para todos os cavalos, são declarações de amor feitas de um lado, aceitas ou rejeitadas de outro. São êxtases de amantes contentes, ou queixas de amantes infelizes, protestos de fidelidade, ou sentimentos de ciúmes, arroubos de prazer, ou prostração de dor; são furores ou desesperos. Não há cena no fim da qual os italianos não saibam encontrar um lugar para alguma dessas árias. Mas uma ópera assim feita, com trechos remendados e peças recosidas, não poderia ser firmemente posta em paralelo com as nossas, que são obras de uma seqüência, de uma justeza e de uma condução maravilhosas.

Nossas óperas têm, além disso, uma grande vantagem sobre as dos italianos, no que diz respeito às vozes, por causa dos baixos [basses-contres] ${ }^{4}$, que são tão comuns para nós e tão 
raros na Itália. Pois, ao juízo de todos os ouvidos, não há nada de mais encantador do que um belo baixo; o simples som desses baixos, que às vezes ouvimos precipitar-se num vazio profundo, tem algo que encanta. Essas grandes vozes fazem vibrar uma quantidade de ar muito maior do que as outras e, conseqüentemente, preenchem com uma harmonia muito mais vasta e agradável os personagens de deuses e de reis, quando é necessário falar em cena um Júpiter, um Netuno, um Príamo, um Agamenão. Nossos atores, com o som de suas vozes grossas, têm outra majestade, diferente da dos italianos, com seus falsetes ou seus falsos baixos [fossets ou leurs fausses Basses $]^{5}$, que não têm nem profundidade nem força. Além disso, a mistura dos baixos com os sopranos $[\text { dessus }]^{6}$ forma um contraste agradável que faz sentir toda a beleza daqueles por oposição a estes, prazer que os italianos nunca experimentam, sendo as vozes de seus músicos, quase todos castrati, inteiramente semelhantes às de suas mulheres.

Além da vantagem da justeza das peças e das diferentes espécies de voz, nós temos ainda a dos coros, das danças e de outros divertimentos [divertissements $]^{7}$, no que nossas óperas superam infinitamente as dos italianos ${ }^{8}$. Estes, em vez de coros e divertimentos que geram uma variedade tão agradável em nossas óperas e que lhes dão até mesmo certo ar de grandeza e de magnificência, têm ordinariamente apenas cenas burlescas de um bufão; de alguma velha que estará apaixonada por um rapaz, ou de um mago que transformará um gato em um pássaro, um violino em uma coruja, e que fará outros rodeios semelhantes que poderiam apenas divertir a platéia [parterre $]^{9}$. E quanto às danças dos italianos, é a maior lástima do mundo, seus dançarinos são homens de uma só peça, sem braços, sem pernas, sem estatura e sem ar.

Quanto aos instrumentos, nossos violinos são superiores aos da Itália, pela fineza e delicadeza da maneira de tocar. Todos os golpes de arco [coups d'archets] dos italianos são demasiado duros quando estão destacados uns dos outros ${ }^{10}$. E quando eles os querem ligar, arranham [viellent ${ }^{11}$ de uma maneira muito desagradável. De mais a mais, além de todos os tipos de instrumentos que estão em uso entre os italianos, nós ainda temos os oboés, que, por seu som igualmente macio e penetrante, têm muitas vantagens sobre os violinos nas árias de mouvement ${ }^{12}$. E as flautas, que tantos homens ilustres ${ }^{13}$ sabem fazer gemer de ao definir o termo italiano Bassista afirma que se trata de "celuy qui chante la plus basse des parties de la musique, vulgairement bassecontre". Na Encyclopédie, a definição não é nada esclarecedora: "acteur qui dans les chœurs de l'opéra $\&$ autres concerts chante la partie de bassecontre. Il y a peu de basse-contres à l'opéra; l'harmonie des chœurs y gagneroit, s'il $y$ en avoit un plus grand nombre" (CAHUSAC, 1751-1772). Rousseau, mais tarde, simplesmente dirá que basses-contres são "les plus graves de toutes les voix, qui chantent la basse sous la basse même, et qu'il ne faut pas confondre avec les contre-basses, qui sont des instruments" (ROUSSEAU, 1826, p. 112-113). O curioso é que na versão de 1753 do texto de Raguenet, La Paix de l'Opéra, a vantagem não está mais nas vozes de basses-contres, mas nas de basses-tailles, que seriam o equivalente da voz do barítono (RAGUENET, 1753, p. 8). Para as convenções do uso desse tipo de voz nas óperas francesas, cf. HOWARD (1989).

5. Não é muito claro o que Raguenet entende por fosset. Poderia ser uma variação na ortografia de fossé, fosso, como se dissesse que os baixos italianos soam como um "buraco". Mais provavelmente seria uma variação de fausset, no sentido de falsete, mas o Dictionnaire de l'Académie française (1694, p.442) informa que fausset é a 
"voix qui contrefait le dessus en Musique, comme qui dirait, Un faux dessus, un dessus qui n'est pas naturel”. Assim, o falsete indicaria apenas uma voz aguda e nunca uma falsa voz grave. Na tradução inglesa anônima do texto de Raguenet, a passagem é traduzida da seguinte maneira: "quite different from that of the feigned basses among the Italians" (RAGUENET, 1946, p.

413), insistindo no caráter

"falso", mas excluindo uma possível tradução para fosset. Mattheson, ao publicar o texto francês e a tradução alemã em seu Critica Musica, traduziu do seguinte modo a passagem: "als die Italiänische Operisten, mit ihren Falsetten oder Stroh Bässen" (MATTHESON, 2003, v. 1, p. 111-112). O autor, na nota g, à p. 111, ainda comenta: "So steht es in der Amsterdammischen

Edition. Es sollte aber geschrieben seyn: Fausset, von faux, falsch weil es einen falschen Discant oder Alt bedeutet. Was wir eigentlich eine Falset Stimme nennen ist wenn ein Sänger der etwan von

Natur einen Baß oder

Tenor singt." Na nota h, à p. 112, Mattheson afirma ainda que o termo "falso baixo" (fausse Basse) não é usado em música e por isso preferiu Stroh Baß.

Finalmente, na edição de 1753 do texto de Raguenet, lê-se: “[...] ceux d'Italie avec leurs faussets ou leurs fausses basses [...]" (RAGUENET, 1753, p. 9). Pelo exposto, optamos por traduzir fosset por falsete, ainda que o termo não seja uma maneira tão tocante nas nossas árias lamentosas e suspirar tão amorosamente em nossas árias ternas.

Enfim, os franceses superam os italianos nas óperas pelo vestuário dos atores e atrizes, o qual é de uma riqueza, de uma magnificência, de uma elegância e de um gosto que ultrapassam tudo o que se vê alhures. Não há, na Europa, dançarinos que se aproximem, como declaram os próprios italianos, dos Combatentes e Ciclopes de Persée ${ }^{14}$, dos Tremedores e dos Ferreiros de $I_{s i s^{15}}$, dos Sonhos funestos de Atys $^{16}$. E as outras entradas [entrées] de balé ${ }^{17}$ são peças originais, tanto pelas árias compostas por Lully, quanto pelos passos que Beauchamp ${ }^{18}$ fez para essas árias. Não se havia visto nada de semelhante no teatro antes desses dois grandes homens. Eles são os inventores e levaram rapidamente essas peças a um grau tão alto de perfeição que ninguém, nem na Itália nem em outro lugar do mundo, soube atingir depois e talvez nunca se atingirá. Nenhuma luta de teatro apresenta uma imagem tão natural da guerra quanto as que os franceses fazem aparecer em cena. Em uma palavra, tudo é executado, nos franceses, com tamanha justeza que nada se contradiz, tudo está ligado, tudo está ordenado com uma seqüência e uma economia admiráveis, a ponto de não haver nenhuma pessoa inteligente e com eqüidade que não concorde que as óperas dos franceses têm a forma de um espetáculo muito mais perfeito do que as dos italianos, e que esse tipo de obra, como espetáculo, é superior na França aos que se vêem na Itália. Eis tudo o que pode ser dito a favor da França, no que concerne à música e às óperas. Vejamos agora o que pode ser dito a favor da Itália nessas duas coisas.

A língua italiana tem uma grande vantagem sobre a francesa para ser cantada, pois todas as suas vogais soam muito bem, enquanto a metade das de língua francesa são vogais mudas, que quase não têm som. De onde, primeiramente, acontece de não sabermos fazer nenhuma cadência $\left[\right.$ cadence ${ }^{19}$ nem passagens ornamentadas [passages] ${ }^{20}$ agradáveis sobre as sílabas em que se encontram tais vogais. E, em segundo lugar, só ouvimos as palavras pela metade; de modo que é necessário adivinhar a metade do que cantam os franceses e que, ao contrário, ouvimos muito distintamente tudo o que dizem os italianos. Além disso, mesmo que todas as vogais da língua italiana soem perfeitamente bem, os músicos ainda escolhem aquelas que melhor se ouvem para fazer suas mais belas passagens ornamenta- 
das. É sobre a vogal $a$ que eles fazem quase todas. E nisso têm razão, pois essa vogal, sendo a de som mais claro, a beleza das passagens ornamentadas aparece mais. Enquanto os franceses as fazem indiferentemente sobre todas as vogais, sobre as mais surdas como sobre as mais sonoras; eles até mesmo as fazem sobre ditongos, como nas palavras chaîne [corrente], gloire [glória], etc., cujo som, sendo confuso e misturado das duas vogais juntas, não poderia ter a clareza e a beleza das vogais simples $^{21}$. Mas isso não é propriamente o material da música. Examinemos o que faz sua essência e forma, a saber, o caráter das árias consideradas em particular, ou em relação às diversas partes de que são compostas as grandes peças.

As árias italianas são mais extremas [detournés] e mais ousadas do que as árias francesas. O caráter é levado mais longe, seja pela ternura, seja pela vivacidade, ou por todas as outras espécies. Os italianos até mesmo unem, às vezes, caracteres que os franceses crêem incompatíveis. Os franceses, nas peças com várias partes, trabalham comumente apenas aquela que é o tema; o italianos, ao contrário, fazem todas, normalmente, igualmente belas e elaboradas. Enfim, o gênio dos últimos é inesgotável para inventar, enquanto o dos primeiros é assaz estreitamente limitado. É o que eu vou tentar fazer de maneira clara [sensible], entrando no detalhe de tudo isso.

Quando se considera a natureza das árias francesas e das italianas, não nos espantaríamos em nada com o fato de os italianos pensarem que nossa música nina e faz adormecer e que é, até mesmo, segundo seu gosto, muito maçante e insípida. Os franceses, nas árias, buscam em todos os lugares o doce, o fácil, o que flui, o que se liga; tudo está no mesmo tom, ou, se muda às vezes, isso é feito com preparação e suavizações [adoucissements] que tornam a ária tão natural e tão contínua [suivi] que, se não se mudasse nada, nada haveria de ousado nem de arriscado; tudo é igual e tudo é unido. Os italianos, ao contrário, passam a todo momento do bequadro ao bemol e do bemol ao bequadro; eles arriscam as cadências [cadences] mais forçadas e as dissonâncias mais irregulares; e suas árias são de um canto tão extremo [détourné], que em nada parecem com todas as compostas por outras naçōes do mundo.

Os músicos franceses se creriam perdidos se fizessem o mínimo contra as regras. Eles adulam, fazem cócegas, respeitam o ouvido, e ainda tremem com o medo de não ter sucesso tradicionalmente usado para um "falso baixo".

6. Dessus também pode ser traduzido por canto ou tiple, dependendo da época e do repertório. De qualquer modo, indica sempre a voz superior, superius. Em francês os termos dessus, hautecontre, taille, basse e outras combinaçôes servem tanto para a classificação das vozes como para as famílias de instrumentos (violinos, violas da gamba, etc.).

7. Divertissements são episódios marcadamente separados da ação e não apresentam nada de necessariamente cômico. É o lugar de coros e danças, das cenas de tempestade, de sono, de vitória, de glória, etc. Cf. DURON (1992).

8. Os coros, balés e outros

"divertimentos" não apareciam comumente nas óperas italianas do final do século XVII e início do século XVIII. A estrutura mais usual das óperas italianas no período era uma seqüência de recitativos e árias, com duetos ao final de um dos atos. Os coros apareciam em geral ao final da ópera, mas com função muito diversa daqueles dos franceses.

9. Parterre indica a parte térrea do teatro, em geral o lugar mais barato, em que o público ficava em pé..

\footnotetext{
10. No original, "lorsqu'ils sont détachez les uns des autres", no sentido de staccato. Veja-se a definição de Brossard para este
} 
termo: "coups d'Archet secs, sans

trainer et bien détouchez

les uns des autres, c'est presque ce que nous apellons en Français, picqué ou pointé" (BROSSARD, 1705 p.114).

11. O verbo vieller segundo o Dictionnaire de l'Académie française (1694, p. 642), significa tocar a vielle, viola de roda, instrumento de cordas de tripa, acionado por uma roda com manivelas. No verbete, ainda se indica que vieller é empregado em sentido figurado e baixo, para quando se usam delongas inúteis em um negócio ou em uma obra. Como em todos

os outros momentos do texto o autor usa os verbos jouer ou toucher quando se refere a tocar instrumentos, acreditamos que aqui haja uma ênfase na crítica à maneira como os instrumentistas italianos tocavam o violino.

12. Novamente existe uma dificuldade quanto à terminologia. Lois Rosow dá uma explicação sobre air de mouvement: "The term, used in the eighteenth century to refer to operatic airs, had been introduced in the seventeenth century to distinguish a metrically regular song from the metrically shifting type of air de cour that was popular at that time" (ROSOW, 1998, p. 260,

nota 5). Podemos assim dizer que, para Raguenet, neste caso, o termo refere-

se a árias com tempo e métrica mais determinados depois de fazer as coisas com toda a regularidade possível. Os italianos, mais ousados, mudam bruscamente de tom e de modo, fazem cadências dobradas e redobradas [cadences doublées \& redoublées] de sete e oito compassos, sobre tons que não pensaríamos capazes de suportar o menor trinado [tremblement $]^{22}$. Fazem notas sustentadas $\left[\right.$ tenues ${ }^{23}$ de uma duração tão prodigiosa, que aqueles que não estão acostumados não se poderiam impedir de, para começar, ficar indignados com tal ousadia, a qual, em seguida, acreditamos não poder jamais admirar suficientemente. Fazem passagens ornamentadas de uma extensão que confunde todos os que as ouvem pela primeira vez. E às vezes eles as fazem até mesmo em tons tão irregulares, que lançam o pavor assim como a surpresa no espírito do ouvinte, o qual crê que todo o concerto vai cair em uma dissonância assustadora. E interessando-o, com isso, pela ruína em que toda a música parece ameaçada, eles o sossegam com cadências $[\text { chutes }]^{24}$ tão regulares, que todos se surpreendem ao ver a harmonia como que renascer da própria dissonância, e tirar sua maior beleza dessas irregularidades que pareciam que iriam destruí-la. Eles arriscam o que há de mais duro e de mais extraordinário, mas o fazem como pessoas que têm o direito de fazê-lo e que têm certeza do sucesso. No sentimento que têm de serem os primeiros do mundo para a música, de dela serem os soberanos e senhores despóticos, eles transpõem suas regras com sobressaltos [saillies] temerários, mas felizes; eles se colocam acima da arte, mas como senhores da arte, que seguem suas leis quando querem e que as ofendem quando lhes agrada; eles insultam a delicadeza do ouvido, o qual os outros só ousariam tocar lisonjeando-a; eles a afrontam, forçam, dominam e a suprimem através de encantos que certamente tiram sua maior força da ousadia com que dela sabem se servir.

Às vezes, ouve-se uma nota sustentada contra a qual os primeiros tons do baixo-contínuo fazem uma dissonância que irrita o ouvido; mas o baixo, continuando a tocar, volta a essa nota sustentada com acordes tão belos, que bem se vê que o músico criou essas dissonâncias apenas para fazer sentir, com mais prazer, os belos acordes para onde rapidamente conduz a harmonia.

Se dermos uma dessas dissonâncias para um francês cantar, ele jamais terá a força para mantê-la com a firmeza necessária 
para ser sustentada, de modo que ela seja bem sucedida. Seu ouvido, acostumado às consonâncias mais doces e mais naturais, fica chocado com sua irregularidade, ele treme ao cantá-la, vacila. Enquanto os italianos, cujo ouvido está desde a juventude afeito a tais dissonâncias e a elas foi acostumado pela força do hábito, são tão firmes sobre o tom mais irregular que sobre o acorde mais belo do mundo tudo cantam com uma ousadia e uma segurança que os torna sempre bem sucedidos.

A música é algo muito comum na Itália. Os italianos cantam desde o berço, cantam todos os dias, cantam em todos os lugares. Um canto natural e unido é, para eles, algo vulgar demais; eles já escutaram demais dessa maneira; o natural, para eles, está gasto [usé]. Para excitar o gosto saciado pelos cantos simples e contínuos é incessantemente necessário passar de um tom a outro e arriscar as passagens ornamentadas mais bizarras e as mais forçadas. Sem isso, não podemos despertá-los nem excitar sua atenção. Mas continuemos o paralelo, com relação aos diversos caracteres das árias.

Como os italianos são muito mais vivos do que os franceses, eles são muito mais sensíveis às paixões e também as exprimem muito mais vivamente em todas as suas produções. Se é necessário fazer uma sinfonia que exprima a tempestade, o furor, eles imprimem tão bem o caráter disso em suas árias que, com freqüência, a realidade não age mais fortemente sobre a alma. Lá tudo é tão vivo, tão agudo, tão penetrante, tão impetuoso e tão inquieto que a imaginação, os sentidos, a alma e o próprio corpo são conduzidos por um enlevo coletivo. Não podemos nos impedir de seguir a rapidez desses movimentos. Uma sinfonia de fúrias agita a alma, revira-a, derruba-a, apesar dela. $\mathrm{O}$ violinista que a executa não pode evitar de ser por ela transportado e de sentir o furor: atormenta seu violino, seu corpo, não é mais senhor de si, agita-se como um possuído e não poderia fazer de outra forma.

Se a sinfonia deve exprimir calma e repouso, ainda que exija um caráter totalmente oposto, eles não a executam com menor sucesso. São tons que descem tanto, que com eles precipitam a alma em sua profundidade. São arcadas com uma duração infinita, prolongadas com um som moribundo que diminui sempre até que expire inteiramente. Suas sinfonias de sono arrebatam a alma dos sentidos e do corpo, suspendem as faculdades e sua ação, a tal ponto que, tão ocupada pela har- do que nas declamações das árias de corte (airs de cour).

13. N. do A. Philibert, Philidor, Descoteaux e os Hoteterres [o autor refere-se a instrumentistas, compositores e construtores de flautas, de várias gerações].

14. Persée, tragédie de P. Quinault, com música e Jean-Baptiste Lully (16321687), estreou em 17 de abril de 1682. Os ciclopes aparecem no Ato II, cenas 8 a 10.

15. Isis, tragédie en musique de P. Quinault, com música e Lully, estreou em 5 de janeiro de 1677 em Saint-Germain en Laye. No Ato IV, cenas 1 e 2, encontra-se o "Coro dos povos dos climas gelados", justamente, os "tremedores" de que fala Raguenet. $\mathrm{Na}$ cena 3 do mesmo ato surge o coro dos ferreiros (ou forjadores).

16. Atys, tragédie en musique de P. Quinault, com música de Lully, estreou em 10 de janeiro de 1676 em Saint-Germain en Laye. A famosa cena do sono é a de número 4 , no Ato III.

17. A entrée de ballet, no balé de corte, é uma cena independente, executada por vários personagens que cantam e dançam. Por extensão, nas obras líricas e dramáticas, é uma passagem de dança e canto executada por um ou mais personagens ao longo de um divertissement. Cf. LECOMTE (1992b). 
18. Pierre Beauchamp $[s]$ (1631-1705), bailarino, coreógrafo e pedagogo. Trabalhou com Lully nos ballets de cour e, junto com Molière, foi criador do gênero comédie-ballet. Cf. LECOMTE (1992).

19. Raguenet parece usar os termos cadence, chute e passage de maneira genérica. $\mathrm{O}$ Dictionnaire de l'Académie française, dá como primeiro significado para cadence "la mésure du son qui règle le mouvement de celui qui danse" e também indica que cadence "se dit aussi du chant, soutenir la cadence, cadence finale, etc.” (1694, p. 139), no sentido de cláusula, encerramento.

Brossard é mais preciso em sua definição: "en Latin clausula ou conclusio, veut dire une cheute ou une conclusion de chant et d'harmonie propre à terminer ou tout à fait, ou en partie une pièce, et aussi se doit faire regulierement en battant, sur la finale, ou la dominante, et quelques fois sur la médiante d'un Mode. C'est ce que l'on doit appeller proprement cadence et non pas comme nos François qui nomment un tremblement cadence, etc." (BROSSARD, 1705,

p. 9). O Dictionnaire de Trévoux (1771, I, p. 316-317) indica diversos significados: o de conclusão de uma frase harmônica, o de finalização de uma frase do canto, o de um ornamento específico (tremblement). No caso de Raguenet, entendemos que se trata do momento em que o cantor faz variaçôes e introduz ornamentações. monia que a possui e que a encanta, ela não mais dá atenção ao resto, como se todos os seus poderes estivessem atados por um sono real.

Enfim, quanto à conformidade da ária com o sentido das palavras, nunca ouvi, em matéria de sinfonias, algo de comparável à que foi executada em Roma, no Oratório de São Jerônimo da Caridade ${ }^{25}$, no dia de São Martinho ${ }^{26}$ do ano de 1697, sobre estas duas palavras: mille saette, mil flechas. Era uma ária cujas notas eram pontuadas como nas gigas. $\mathrm{O}$ caráter dessa ária imprimia tão vivamente na alma a idéia de flecha e a força dessa idéia seduzia a imaginação a ponto de cada violino parecer um arco [arc] e todos os arcos dos instrumentos [archets], flechas lançadas, cujas pontas pareciam dardejar a sinfonia em todas as partes. Não poderíamos ouvir nada de mais engenhoso e de mais felizmente expresso. Assim, seja quando as árias têm um caráter vivo ou terno, seja quando são impetuosas ou languescentes, também nisso os italianos superam os franceses. Mas eles, além do mais, fazem algo que nem os músicos franceses nem os de todas as outras nações poderiam e nunca puderam fazer: eles unem, às vezes, de maneira surpreendente, a ternura com a vivacidade, como se vê na famosa ária Mai non si vidde [sic] ancor piú bella fedeltà etc. [Nunca se viu mais bela fidelidade], que é a mais doce e a mais terna do mundo, cuja sinfonia, apesar disso, é a mais viva e a mais excitante [piquante] que se possa ouvir ${ }^{27}$. Eles aliam tais caracteres opostos de maneira que, bem longe de estragar um contrário com seu contrário, sempre se embeleza um com o outro.

Passemos agora das árias simples para as peças compostas com várias partes. Que vantagem teriam os italianos sobre os franceses? Não vi nenhum músico, na França, que não convenha que os italianos sabem melhor inverter e cruzar [as vozes] do que os franceses. Entre nós, a voz de primeiro soprano [premier dessus] ${ }^{28}$ é comumente muito bela; mas o segundo só poderia descer tanto quanto o faríamos descer. $\mathrm{Na}$ Itália, o soprano [dessus] é três ou quatro tons mais alto do que na França, a ponto de o segundo soprano estar, por isso, em um tom alto o suficiente para ter tanta beleza quanto nossos próprios primeiros sopranos [premiers dessus]. Além disso, as três partes [de um trio] são igualmente tão belas, que não poderíamos dizer qual é o tema [sujet]. Lully fez alguns trios com tal 
beleza, mas são em pequeno número; enquanto quase todos os italianos têm esse caráter.

Mas é nas peças com mais partes que melhor aparece a vantagem que os músicos da Itália têm sobre os da França quanto à composição. Na França, já é muito quando o tema é belo; é raro que as partes que o acompanham tenham apenas um canto contínuo. Encontramos, às vezes, baixos-contínuos que tocam sempre e que os franceses acham admiráveis por causa disso. Mas, nessas ocasiōes, as vozes superiores são pouca coisa, deixam de ser o tema, e então o baixo é que se torna o tema. Quanto aos acompanhamentos de violino, eles são, na maior parte, simples arcadas, ouvidas em intervalos, que nada têm de um canto ligado e contínuo e que servem apenas para fazer ouvir, de tempos em tempos, algum acorde. $\mathrm{Na}$ Itália, ao contrário, a primeira voz, a segunda, o baixo-contínuo e todas as outras partes da composição das peças mais cheias [remplies] são igualmente trabalhadas. Os violinos tocam sempre partes cujo canto é comumente tão belo quanto a ária em questão; também acontece freqüentemente de, depois de termos ouvido algo da ária que achamos encantadora, sermos imperceptivelmente conduzidos pelas partes acompanhantes, que não encantam menos e que fazem abandonar o tema para serem seguidas. Tudo é de uma beleza tão igual que não se poderia dizer qual é a parte predominante. Às vezes o baixo-contínuo acompanha a tal ponto de, ao ouvi-lo, não pensarmos de modo algum no tema. Outras vezes, o tema conduz de tal maneira que não prestamos nenhuma atenção ao baixo-contínuo; no momento seguinte, os acompanhamentos de violino encantam de tal maneira que não escutamos nem o baixo-contínuo, nem o tema. Uma alma não é suficiente para sentir a beleza de todas as partes; seria necessário multiplicar-se para seguir e saborear, ao mesmo tempo, três ou quatro coisas igualmente tão belas. Somos arrebatados, encantados, extasiados de prazer; é necessário soltar um grito de espanto para se aliviar; ninguém pode evitá-lo; esperamos com impaciência o fim de cada ária para respirar. Com freqüência não se pode esperar até o fim, interrompe-se o músico com gritos e aplausos infinitos; a música italiana produz, todos os dias, esses efeitos. Não há ninguém que tenha viajado à Itália e que não tenha sido mil vezes testemunha disso; nunca se experimentou nada de semelhante em nenhum outro país. São
20. Passage tem um signicado preciso de ornamentação em que o músico exibe seu virtuosismo. O Dictionnaire de l'Académie française (1694, p. 194) precisa que se trata de "un certain roulement de voix, qui se fait en passant d'une note à une autre". BROSSARD (1705, p. 72), informa que se trata de "une suite de chant composée de plusieurs petites nottes [sic] comme croches, doubles croches, etc.; qui dure une, deux ou trois mesures tout au plus". O termo em português "passagem" não tem o mesmo significado e por isso optamos por "passagem ornamentada". Poderia ser traduzido como cadência, mas este uso diz respeito a uma prática mais tardia do século XVIII. Não deve ser confundido nem com cadence nem com chute.

21. Para uma discussão sobre o assunto, com uma conclusão favorável aos franceses, veja-se GRIMAREST (1707, p. 193-231).

22. BROSSARD (1705, p. 169-170), no verbete trillo, indica: "C'est souvent la marque qu'on doit battre fort vite alternativement, ou l'un après l'autre deux Sons en degré conjoints comme fa, mi, ou mi, re, \&c. De manière qu'on commence par le plus haut, \& qu'on finisse par le plus bas, \& c'est là proprement la Cadence ou le Tremblement à la Françoise". Não deve ser confundido com o trillo à italiana, que é a repetição de uma mesma nota, no 
início de maneira lenta e depois rapidamente, chamado também de double cadence ou tour de gosier.

23. O tradutor anônimo da versão inglesa

(RAGUENET, 1946, p.

418) indica, como se fosse uma nota de Raguenet, que

se trata da messa di voce

italiana. A palavra inglesa usada é swelling. Ver nota 19.

25. A igreja de São Jerônimo da Caridade (San Girolamo della

Carità) situa-se à Via Monserrato, próximo à praça Farnese em Roma. Em 1551, S. Filipe Neri mudou-se para um edifício ao lado da igreja e nela fundou o oratório, com representações sacras musicadas. Smither, em seu longo estudo sobre os oratórios, confirma a importância do oratório de São Jerônimo, junto com o de Santa Maria in

Vallicella (Chiesa Nuova):

"The chief Roman centers of oratorio performance in a devotional context continued to be the oratories - particularly those of San Girolamo della Carità, the Chiesa Nuova, and Crocifisso.

As in the previous period, oratorios in Italian were performed in the first two locations primarily on Sundays and other feast days in the winter months; Crocifisso continued to restrict its oratorios to the Latin language and to the Fridays of Lent. Well before the 1660s these oratorios had become

famous musical centers, as pointed out above; yet belezas de um grau de excelência que a imaginação não poderia atingir antes de ouvi-las; e além do que nada poderíamos imaginar, depois de as termos ouvido.

Enfim, os italianos são inesgotáveis na produção de peças compostas com tantas belas partes, enquanto o gênio dos franceses é extremamente limitado nisso. Na França, um compositor acredita ter feito muito ao diversificar o tema. Quanto aos acompanhamentos, não há nada de semelhante: são sempre os mesmos acordes, as mesmas cadências [chutes], nenhuma variedade, nenhuma surpresa, prevemos tudo. Os músicos franceses pilham-se uns aos outros, ou de tal maneira se copiam que quase todas as suas obras são semelhantes. $\mathrm{Na}$ Itália, ao contrário, os gênios são inesgotáveis e infinitos pela quantidade e pela diversidade das árias. A quantidade é inumerável, sem nenhum exagero, e, contudo, seria muito difícil encontrar duas árias que se assemelhem. Nós admiramos, todos os dias, a fecundidade do gênio de Lully na composição do grande número de belas árias completamente diferentes que ele fez. Jamais um músico apareceu na França com tanto talento para a música, não há ninguém que discorde disso. E não preciso de muito para fazer conhecer o quanto o gênio dos italianos é superior ao dos franceses na invenção e na composição em matéria de música. Pois, enfim, esse homem excelente, cujas obras os franceses opõem àquelas dos maiores mestres da Itália, era italiano. Ele ultrapassou todos os nossos mestres, mesmo no gosto francês. Para estabelecer então a igualdade entre as duas nações no que concerne à arte da música seria necessário produzir o exemplo de algum francês que tivesse sido excelente na Itália, acima dos maiores mestres desse país, no próprio gosto dos italianos. E é isso que ainda não vimos até o presente. Além do mais, Lully é o único que jamais apareceu na França com esse gênio superior para a música, e a Itália está cheia de mestres que têm, pelo menos, sua força. Eles existem em Roma, em Nápoles, em Florença, em Veneza, em Bolonha, em Milão, em Turim e sempre existiram em todos os tempos. Vimos os Luigi, os Carissimi, os Melani, os Legrenzi; a estes, sucederam os Scarlatti, os Bononcini, os Corelli e os Bassani que ainda vivem e que encantam toda a Europa com suas excelentes produçóes ${ }^{29}$. Os primeiros pareciam haver esgotado todas as belezas da arte; contudo, os segundos, pelo menos, os igualaram, em uma infinidade de 
obras de um caráter completamente novo. Eles se elevam, a cada dia, a ponto de parecerem dever ainda ir além de todos os séculos passados. E isso, em todos os lugares da Itália; enquanto na França, um desses grandes mestres é visto como uma fênix, só vemos um deles por vez em todo o reino, e é necessário um século inteiro para produzi-lo. Ainda nos desesperamos que todos os séculos juntos nunca produzam um homem capaz de substituir Lully. Não há, então, como todo o mundo vê, nenhuma comparação a fazer entre os italianos e franceses quanto ao gênio da música.

Nada se faz de belo na França desde a morte de Lully; assim, aqueles que amam a música estão sem prazer em sem esperança. Mas eles só precisam ir à Itália, e eu lhes digo que seu cérebro, ainda que esteja habituado aos traços da música francesa, será como uma mesa de trabalho [table d'attente] completamente nova para a música italiana, sendo que as árias italianas em nada se parecem com as francesas, o que nunca se compreenderá, a menos que se vá à Itália. Pois os franceses não poderiam imaginar que se pode fazer algo de mais tocante, em matéria de música, do que as belas árias que se ouvem na França. Eis as vantagens que os italianos têm sobre os franceses, na música considerada em geral. Vejamos agora as que eles têm com relação às óperas. Para observar alguma ordem em um número tão grande de coisas diferentes que concorrem para formar uma ópera, eu começaria pela música, da qual eu diria duas palavras sobre o recitativo e a sinfonia; depois, eu falaria das vozes, dos que cantam nas óperas, considerados como músicos e como atores; dos instrumentos e dos que os tocam; enfim, das decorações e das máquinas.

Não há nenhum lugar frágil nas óperas da Itália, como nas da França. Não se distingue a bela cena; todas as canções têm a mesma força e não há nenhuma no fim da qual não se exclame e se aplauda. Enquanto em nossas óperas há não sei quantas cenas languescentes e árias insípidas que não poderiam tocar a quem quer que seja, nem agradar, em nada, a ninguém.

É verdade que nosso recitativo é muito mais belo do que o dos italianos, que é simples e unido demais, que é sempre igual, que não é propriamente um canto, pois eles apenas falam, por assim dizer, no recitativo. Quase não há nada de inflexão nem de modulação nesse pretenso canto. Contudo, o que há de admirável é que as partes que servem de acom- they had not been merely concert halls but also places of prayer and preaching: the music had been viewed as a spiritual instruction as well as an entertainment" (SMITHER, 1977, p. 259). Para outras informaçōes, cf. FRANCHI (2002). Não foi possível identificar qual seria o oratório mencionado por Raguenet.

26. 11 de novembro.

27. Ária do final do primeiro ato da ópera Il Trionfo di Camilla, Regina de Volsci, libreto de Silvio Stampiglia, música de G. Bononcini, estreada no teatro $S$. Bartolomeo de Nápoles em 27 de dezembro de 1696.

28. Dessus, como já visto, é a voz de soprano, que podia ser dividida em premiers e seconds dessus, ou, de acordo com outra nomenclatura, em dessus e bas-dessus. Raguenet mostra aqui o uso diferenciado das vozes superiores nas duas tradições.

29. Raguenet nomeia músicos italianos de várias geraçōes: Luigi Rossi (1597/8-1653); G. Carissimi (1605-1674); provavelmente Jacopo Melani (1639-1703), já que Alessandro morreu em 1703; Giovanni Legrenzi (1626-1690), Alessandro Scarlatti (1660-1725),

Giovanni Bononcini (1670-1747), Archangelo Corelli (1653-1713) e

Giovanni Battista Bassani (1657-1716). 
30. Na tradução inglesa (RAGUENET, 1946, p. 426), "chuckle in the throat". O sentido é de uma articulação das notas feita com a glote. panhamento a essa salmodia são excelentes, pois o gênio dos italianos para a composição é tão maravilhoso que eles sabem encontrar acordes encantadores, mesmo ao som da voz de uma pessoa que simplesmente fala sem cantar, o que nunca se viu nem se poderá ver em nenhum outro lugar do mundo.

O mesmo ocorre na sinfonia deles, em particular com relação à nossa, como em sua música em geral. Em nossas óperas ela é, em diversos lugares, muito seca e tediosa, enquanto nas da Itália ela é sempre doce [moelleuse], cheia de acordes os mais harmoniosos; e isso sem nenhuma irregularidade [inégalité].

Eu disse, no começo deste paralelo, que nós tínhamos uma grande vantagem sobre os italianos por causa dos baixos [basses-contres], que são tão comuns entre nós e tão raros na Itália. Mas que vantagens os italianos não têm sobre nós, quanto às óperas, por seus castrati que são sem número e dos quais não temos nenhum na França? As vozes de mulher são, verdadeiramente, tão doces e agradáveis, aqui, quanto as dessas espécies de homens. Mas falta muito para que elas sejam tão fortes e tão penetrantes; não há nenhuma voz no mundo, nem de homem nem de mulher, tão flexível quanto a dos castrati. Elas são claras [nettes], tocantes, penetram até a alma.

Ouve-se uma sinfonia tão encantadora que não poderíamos imaginar nada além dela. Contudo, percebemos que é apenas o acompanhamento de uma ária ainda mais bela, cantada por uma dessas vozes, que, com um som o mais brilhante e ao mesmo tempo o mais doce, penetra na sinfonia e se eleva sobre todos os instrumentos com um deleite [agrément] que não poderíamos descrever; é necessário ouvi-la.

São gorjeios [gosiers] e sons da voz de rouxinol, são fôlegos a perder de vista e que quase nos interrompem a respiração; fôlegos infinitos, por meio dos quais eles executam passagens ornamentadas de não sei quantos compassos, fazem ecos dessas mesmas passagens, sustentam notas de uma duração prodigiosa, com um golpe de glote [coup de gorge $]^{30}$ semelhante à dos rouxinóis, ainda fazem cadências [cadences] com a mesma duração.

De resto, essas vozes doces e rouxinoleantes são encantadas na boca dos atores que fazem o personagem apaixonado. Nada é mais tocante do que a expressão de seus sofrimentos, formada com esses sons de voz tão ternos e tão passionais. E os italianos têm, nisso, uma grande vantagem sobre os 
apaixonados de nossos teatros, cuja voz grossa e masculina é constantemente menos apropriada às doçuras que eles dizem a suas amantes. Além do mais, como essas vozes são tão fortes quanto doces, ouvimos claramente tudo o que se canta nos teatros italianos, enquanto perdemos a metade nos franceses, a menos que estejamos muito perto e que possamos adivinhá-lo. São, comumente, garotinhas sem pulmões, sem força e sem fôlego que cantam na França a voz de soprano [dessus]; enquanto essa mesma parte é sempre cantada na Itália por homens fortes, cuja voz firme e ressoante se faz ouvir com clareza nos lugares mais vastos, sem que se perca uma sílaba em qualquer lugar no teatro.

Mas a maior vantagem que os italianos têm sobre os franceses, por meio dos castrati, quanto às vozes, é que elas duram trinta ou quarenta anos, enquanto as das nossas mulheres não conservam mais do que dez ou doze anos sua força e beleza. De modo que uma atriz, apenas formada para o teatro, perde sua voz e é necessário tomar, em seu lugar, novas atrizes, que não são boas na ação, quando não são boas no canto, e para quem são necessários cinco ou seis anos de exercício para tornarem-se capazes de desempenhar os papéis um pouco consideráveis. É muito, na França, quando há cinco ou seis boas vozes em trinta ou quarenta atores ou atrizes que se encontram em uma ópera. Na Itália, elas são todas mais ou menos iguais e raramente são usadas vozes medíocres, porque se podem escolher quantas se quiser.

Quanto aos atores, podemos encará-los ou como músicos que têm sua parte para cantar, ou como personagens de teatro que têm um papel a desempenhar. E os italianos, tanto em um quanto em outro desses aspectos, ultrapassam ainda os franceses.

Aqui, há sempre em uma ópera um ator defeituoso [véreux $]^{31}$, que falha no canto ou no ritmo, ou uma atriz fraca, que canta desafinado e que desculpamos por ela ainda não estar pronta para o teatro, que não tem voz e a quem se desculpa, com frequiência, porque ela agrada e tem uma bela figura. Isso nunca acontece nas óperas da Itália; não há nenhuma voz que não seja pelo menos suportável. Não há nenhum homem nem mulher que não cante perfeitamente sua parte com vozes de beleza mediana; eles arrebatam todos os que os ouvem, por força das passagens ornamentadas que executam, pois não se faz, em lugar algum, a música como se faz na Itália. E não há
31. Véreux é aquilo que contém ver, um verme. Em sentido figurado, pode significar corrompido, desonesto, mas também, insignificante, defeituoso. O Dictionnaire de l'Académie française, (1694, v. 2, p. 630), no verbete Vereux, informa que, no sentido figurado, "defectueux, qui n'a point les bonnes qualitez qu'il paroit avoir". Um dos exemplos dados reporta-se justamente à qualidade dos atores de uma companhia : "Dans cette compagnielà, ils ne sont pas tous habiles, il y en a bien de véreux". Na tradução inglesa, "insignificant actor" (RAGUENET, 1946, p. 427). Mattheson diz "trifft man allemahl einen oder andern würmstichichen Acteur an" (MATTHESON, 2003, p. 144). 
32. Segundo o tradutor inglês (RAGUENET, 1946 , p. 429), nem os italianos nem os franceses usavam tal palavra e a intenção de Raguenet seria, na verdade, a de dar o exemplo da messa di voce. motivo para surpreender-se com isso; os italianos fazem um estudo da música como nós fazemos para aprender a ler. Há, na Itália, escolas onde as crianças vão aprender a cantar, como elas vão, na França, aprender a ler. Elas vão para essas escolas desde a mais tenra idade e lá permanecem nove ou dez anos, de modo que lá elas cantam como aqui nós lemos quando bem aprendemos a ler, ou seja, com firmeza, com segurança e mesmo sem pensar. Os italianos cantam até mesmo o que eles nunca viram, sem vacilar, como nós lemos sem hesitar um livro que nunca lemos, quando sabemos ler bem. Os italianos estudam música apenas uma vez, mas aprendem até o máximo de perfeição. Os franceses estudam tanto quanto, mas é necessário que estudem por toda a vida, pois, a cada nova peça que se apresenta na França, é preciso que os músicos a estudem e a aprendam para bem cantá-la. É necessário fazer uma infinidade de ensaios particulares de uma ópera para colocá-la no ponto de ser representada em público. Um começa muito cedo, outro muito tarde; um desafina, o outro falha no ritmo; o maestro de música se atormenta com a mão e com a voz, faz cem contorções de todos os membros de seu corpo e, com isso, sofre muito para chegar ao final. Os italianos, ao contrário, são tão consumados e, por assim dizer, tão infalíveis na música, que uma ópera inteira é executada com o máximo de justeza, até mesmo sem se marcar o ritmo, ou sem se saber quem é o maestro que a executa. Eles acrescentam a essa justeza todos os ornamentos [agréments] que uma ária é capaz de receber, fazem cem tipos de passagens ornamentadas e tudo isso brincando; fazem, em seus gorjeios, ecos de uma fineza encantadora. Os franceses não sabem o que são tais ecos. ${ }^{32}$

Nas árias ternas, eles diminuem imperceptivelmente suas vozes e a deixam enfim morrer no final de uma ária. São belezas de máxima delicadeza; delicadeza não apenas desconhecida, mas ainda impossível aos franceses, cujos sopranos têm tão pouca força que, por pouco que viessem a diminuir, se extinguiriam inteiramente e não poderíamos mais ouvi-los. Esses ecos e diminuiçóes de voz conferem tanto prazer às árias italianas, que com freqüência o próprio compositor os acham mais belos na boca de quem canta do que em seu pensamento. $\mathrm{E}$ os italianos têm, nisso, uma dupla vantagem sobre os franceses em suas óperas, o que os faz cantar melhor do que nós, 
também porque são melhores atores. Pois, fazendo um jogo de música e cantando com toda a justeza possível sem serem obrigados a prestar atenção nem ao ritmo nem a outra regra, eles podem aplicar-se totalmente a acomodar seu exterior à ação. E prestando atenção apenas em entrar nas paixōes e em compor seus gestos, para eles é muito mais fácil ser bons atores do que para os franceses, que, não sabendo tão bem música, são com freqüência obrigados a se ocupar inteiramente do cuidado em executar as regras. Não temos um só homem capaz de fazer o personagem de um amante apaixonado em nossas óperas, com exceção de Dumény. Mas além de ele desafinar muito e de fazer pouca música, falta muito para que sua voz seja tão agradável e bela quanto a dos castrati da Itália.

Se uma atriz principal, como a Rochoix ${ }^{34}$, vier a desaparecer, não apenas Paris, mas toda a França não poderia fornecer outra que pudesse substituí-la. Na Itália, para um ator ou uma atriz que faltar rapidamente se encontrariam outros dez, pois todos os italianos nascem comediantes [comédiens] ${ }^{35}$ e são tão excelentes atores quanto músicos. Suas velhas são personagens incomparáveis, seus bufōes valem o que nunca vimos de melhor nesse gênero em nossos teatros.

Além disso, os italianos têm ainda uma vantagem sobre nós através de seus castrati, pois eles fazem o personagem que quiserem, uma mulher ou um homem, segundo a necessidade. Pois os castrati estão tão acostumados a fazer papéis de mulher que as melhores atrizes do mundo não são melhores do que eles. Eles têm a voz tão doce quanto a delas e a têm muito mais forte; eles são maiores do que o comum das mulheres e, por isso, têm mais majestade do que elas. São até mesmo, em geral, mais belos como mulheres do que as próprias mulheres. Ferini ${ }^{36}$, por exemplo, que em 1698 fazia em Roma o personagem de Sibaris na ópera Temistocles ${ }^{37}$, é maior e mais belo do que as mulheres em geral; ele tem um não sei que de nobre e de modesto na fisionomia. Vestido como princesa persa, como ele estava, com o turbante e o penacho, tinha um ar de rainha e de imperatriz. E talvez nunca se tenha visto uma mulher mais bela no mundo do que ele parecia com essa roupa. A Itália está cheia desse tipo de gente, encontramos em todos os lugares atores e atrizes para escolher. Eu vi, em Roma, um homem que era tão bom em música quanto os mais hábeis de nossas óperas; além disso, era excelente
33. Ou Duménil,

Duméni, Du Mesnil, Du Mesny, morreu em 1715. Cozinheiro do intendente de Montauban, foi treinado por Lully, estreando em 1677 na Académie Royale. A partir de Persée (1682) até 1700 , criou todos os grandes papéis de haute-contre de Lully e de seus sucessores. Era o par habitual de Marthe Le Rochois e, segundo LEGRAND (1992), foi o ator mais célebre de seu tempo.

34. Marthe [Marie] Le Rochois (1658-1728). Cantora, talvez educada por Lambert, antes de estrear na Académie Royale e de ser formada por Lully. Foi a grande intérprete dos principais papéis de obras de Lully, Charpentier e outros. Cf. LEGRAND (1992b). O comentário do tradutor inglês sobre a atriz é muito cáustico: "I saw that woman in Paris; she was a good figure enough and had a tolerable voice, but then she was a wretched actress and sung insufferably out of tune" (RAGUENET, 1946, p. 430).

35.Comédien tem o sentido geral de ator, assim como Comédie pode ser entendida como qualquer peça de teatro, seja uma tragédia, uma tragicomédia, uma pastoral, etc. Em português, o mesmo sentido por extensão é possível e, desse modo, preferimos manter o termo comediante, inclusive porque "ator" aparece em seguida na mesma frase. 
36. Talvez Antonio Romolo Fer[r]ini, soprano, mencionado em HILL

(1986, p. 145, nota

73). Também um certo

Ferini é mencionado na apresentação do Oratório

da Ressureição (La

Resurrezione), de Handel,

no Palazzo Ruspoli em

1708. Cf. KIRKENDALE

(1967, p. 256).

37. Trata-se provavelmente da obra Temistocle in bando, com texto de

A. Morselli e música de G. Antonio Zanettini (ou Giannettini, 1648-

1721). A estréia da ópera aconteceu no teatro de

S. Cassiano em Veneza, em 1682. Existe contudo o libreto romano da mesma ópera, que indica a apresentação em Roma em 1698 no teatro Capranica: Temistocle in bando, dramma per musica. Da rappresentarsi nel nuovo Teatro dell'Illustrissimi Signori Capranica, l'anno 1698. Roma: Gaetano Zenobi [et al.], 1698. Os personagens são: Temistocle, Serse,

Ersilla, Sibari, Cleofanto, Artabano, Nicomede e

Delfo.

38. Trata-se ou de Jacques Raisin (?-c. 1700) ou de Jean-Baptiste Raisin (16561693), irmão de Jacques, atores franceses, ambos pertencentes à trupe do Delfim.

39. Segundo o tradutor inglês (RAGUENET,

1946, p. 431): “The lawyer here mentioned is called

Paciani, a man well known

in Rome; his performances on the theatre are purely for his pleasure". ator e, pelo menos, valia tanto quanto nosso Arlequim e nosso Raisin $^{38}$. Entretanto, esse homem não era nem músico nem comediante de profissão; era um procurador que deixava seus afazeres durante o Carnaval para assumir um papel na ópera, e que tratava de suas obrigações no resto do ano. ${ }^{39}$ Assim, é muito mais fácil, como se vê, fazer executar uma ópera na Itália do que na França.

Os italianos ainda têm, nos instrumentos e naqueles que os tocam, a mesma vantagem que têm sobre nós no que diz respeito às vozes e pessoas que cantam. Seus violinos são montados com cordas mais grossas do que as nossas, têm arcos mais longos e eles sabem tirar de seus instrumentos mais som do que nós. Para mim, a primeira vez que ouvi a orquestra de nossa ópera, ao voltar da Itália, a idéia da força desses sons, que ainda me era presente, fez-me achar os de nossos violinos tão fracos que pensei que todos tinham surdinas. Seus arqui-alaúdes são maiores do que nossas teorbas; quanto ao som, tudo é a metade mais forte. Seus violoncelos [basses de violon $]^{40}$ são maiores que os nossos e todos os que juntamos, em nossas óperas, não fazem um zumbido [bourdonnement] tão forte quanto dois desses grandes baixos nas óperas italianas. É certamente um instrumento que nos falta na França, esses baixos de uma profundidade que fazem, na Itália, uma base admirável sobre a qual todo o concerto é como que sustentado. É um fundamento seguro e ainda mais sólido quanto mais baixo e mais profundo. É um som robusto e suave que enche o ar com uma harmonia agradável em uma esfera de ação que se estende até as extremidades dos lugares mais vastos. $\mathrm{O}$ som de suas sinfonias é levado pelo ar até as abóbadas nas igrejas e até o céu nos lugares abertos. E na França há muito poucos que se aproximam dos que tocam esses instrumentos. Vemos, na Itália, crianças de catorze a quinze anos com um violoncelo [basse de violon] ou um violino [dessus de violon] tocar admiravelmente bem sinfonias que nunca viram, mas sinfonias de uma execução que desmontaria nossas pessoas mais hábeis. $\mathrm{E}$ isso, freqüentemente por cima dos ombros de duas ou três pessoas que estão na frente deles, a quatro ou cinco passos da tablatura. Vêem-se esses pequenos pescoços retorcidos [torticolis] lançar apenas um olhar enviesado sobre o livro e conseguir as coisas mais difíceis à primeira vista. Não se bate o compasso nas orquestras da Itália e, contudo, nunca se vê 
alguém perder o tempo, nem o tom. É necessária toda Paris para formar uma bela orquestra e não encontraríamos duas como a da ópera. Em Roma, onde não há um décimo das pessoas de Paris, encontraríamos com o que formar sete ou oito orquestras, compostas de cravos, violinos e teorbas, todas igualmente repletas. Mas aquilo em que, principalmente, as orquestras da Itália superam as francesas é que os maiores maestros não desdenham de nelas tocar. Eu vi, em Roma, em uma mesma ópera, Corelli, Pasquini e Gaetani ${ }^{41}$, que são continuadamente os primeiros homens do mundo no violino, no cravo e na teorba ou arquialaúde. Também são pessoas a quem se dá, por um mês ou seis semanas no máximo, trezentas ou quatrocentas pistolas ${ }^{42}$. É a maneira como se tratam e se pagam os músicos, a qual é causa, em parte, de que haja e de que sempre haverá muito mais músicos entre os italianos do que aqui. Na França, nós os desprezamos como pessoas de uma profissão baixa. Na Itália, são estimados e acariciados como homens ilustres. Eles fazem fortunas muito consideráveis entre os italianos. E, aqui, mal e mal ganham para viver; daí vem que há dez vezes mais pessoas que se ligam à música do que na França. E entre um número maior de pessoas que a ela se dedicam é natural que, mesmo todas as coisas sendo iguais, haja um número maior que tenha sucesso. Nada é mais comum naquele país do que os instrumentistas, os músicos e a música. Os cantores da praça Navona em Roma, e os da ponte do Rialto em Veneza, que são, lá, o que são aqui os cantores do Pont-Neuf, com freqüência juntam-se, três ou quatro, dos quais um toca o violino [dessus de violon], o outro o baixo e os outros a teorba ou a guitarra. Eles cantam, com isso, em partes e acompanham-se muito bem com seus instrumentos. $\mathrm{Na}$ França, fazem-se concertos que não valem mais do que isso.

Enfim, quanto às decorações e máquinas, as óperas da Itália superam ainda mais as da França. Os camarotes são muito mais magníficos, a abertura do teatro é muito mais alta e mais larga, e as pinturas de nossas decorações são, certamente, apenas rabiscos em comparação com as dos italianos. Vemos imitação de estátuas de mármore e de estuque, belas como as mais belas antiguidades de Roma; palácios, colunatas, galerias, partes de arquitetura de uma grandeza e de uma magnificência acima de todos os edifícios que se vêem no mundo; perspectivas que enganam o juízo assim como os olhos daqueles
40. A família das cordas francesas é diferente da italiana: dessus, hautecontre, quinte, taille e basse. Os nomes indicam, na verdade, a relação com a altura e a função de instrumentos e tipos de vozes. O basse de violon é uma espécie de violoncelo francês, "de tamanho superior ao do violoncelo comum, cuja primeira notícia procede dos '24 Violons du Roi' com a seguinte afinação":

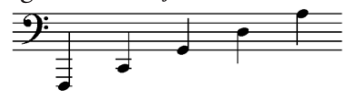

ANDRÉS (1995, p. 475).

41. Archangelo Corelli, Bernardo Pasquini (16371710) e Giuseppe Gaetani (?-?).

42. Pistoles, no original. O Dictionnaire de l'Académie française (1694, p. 243)., informa que se trata de "moeda de ouro estrangeira, com peso de um luís de ouro ou equivalente a dez francos". 
42. Pistoles, no original. O Dictionnaire de l'Académie française (1694, p. 243)., informa que se trata de "moeda de ouro estrangeira, com peso de um luís de ouro ou equivalente a dez francos".

43. O tradutor inglês (RAGUENET, 1946 , p. 434 , nota 37 ) afirma que o autor da pintura do Coliseu é o padre Andrea Pozzo. Segundo V. Martinelli, não restou nenhuma documentação gráfica direta dos cenários realizados pelo padre Pozzo. O autor lembra que existe uma prancha no tratado de autoria de

Pozzo (Prospettiva de'

Pittori e architetti ..., Roma, I, II, 1693-1700) com desenhos do Coliseu. Além disso, um desenho de 1696 atribuído a Pozzo contém diversas indicações de como representar uma "arquitetura redonda" em um teatro para "arquitetura quadrada”. Ambas as imagens estão reproduzidas em MARTINELLI, (1996, p. 94-113).

44. Da sala privada no palácio homônimo, foi criado em 1694 o teatro

Capranica, com planta em $\mathrm{U}$, segundo o projeto de

Carlo Buratti. O teatro romano foi um dois mais importantes para apresentaçóes de ópera até a metade do século XVIII.

45. Filippo Acciaiuoli (1637-1700), importante cenógrafo e empresário de ópera. que conhecem todo o segredo da arte; vistas de uma extensão imensa em espaços que não têm trinta pés de profundidade. Eles até mesmo fazem aparecer comumente os mais soberbos edifícios dos antigos romanos, dos quais vemos apenas os restos, como o Coliseu, que eu vi no Colégio Romano em 1698, no mesmo estado em que ele se encontrava no tempo de Vespasiano, que fez construir esse célebre anfiteatro, a tal ponto de essas decorações serem não apenas muito agradáveis, mas, ainda, muito instrutivas.

Quanto às máquinas, não creio que o espírito humano possa levar a invenção ainda mais longe do que na Itália. Vi, em Turim, em 1697, Orfeu que, em uma ópera, encantava, com sua bela voz, os animais. Havia de todos os tipos: javalis, leões, ursos; nada poderia ser mais natural e mais bem contrafeito. Um macaco que lá estava fez cem brincadeiras, as mais belas do mundo, subindo sobre as costas dos outros animais, raspando suas cabeças com sua mão e fazendo todas as outras macaquices próprias dessas espécie. Um dia, em Veneza, vimos aparecer um elefante no teatro; em um instante, essa grande máquina se desmembrou e um exército apareceu em cena, em seu lugar. Todos os soldados, apenas pelo arranjo de seus escudos, formavam esse elefante de uma maneira tão perfeita, como se fosse um elefante natural e verdadeiro.

Vi, em Roma, em 1698, um fantasma de mulher cercado de guardas entrar no teatro Capranica ${ }^{44}$. Enquanto o fantasma estendia os braços e desdobrava suas vestes, formou-se todo um palácio com sua fachada, suas alas, seu corpo principal e corpos avançados, tudo como uma arquitetura encantada. Os guardas tiveram apenas de bater suas alabardas e elas rapidamente foram transformadas em jatos de água, em cascadas e em árvores que fizeram aparecer um jardim encantador diante do palácio. Não poderíamos ver algo de mais repentino do que essas transformações, nada de mais engenhoso e maravilhoso. Também são ordinariamente os mais belos espíritos da Itália que se dão ao prazer de inventar tais máquinas, pessoas, com freqüência, de primeira qualidade que presenteiam o público com esse tipo de espetáculos, sem nenhum interesse. Era o Cavalheiro Acciaioli, irmão do cardeal de mesmo nome, que cuidava das máquinas do teatro Capranica em 1698.

Eis, ao que me parece, mais ou menos tudo o que se poderia dizer da música francesa e da música italiana em um para- 
lelo. Eu apenas acrescentaria uma coisa, a favor das óperas da Itália, que confirma tudo o que disse em seu benefício. É que, ainda que não haja nem coros nem divertimentos e que elas durem cinco ou seis horas, nunca nos entediamos. Enquanto após algumas representações das nossas, que duram a metade, há muito poucas pessoas que não estejam saciadas e que não se entediem.

\section{REFERÊNCIAS.}

ANDRÉS, R. Diccionario de instrumentos musicales. Barcelona: Bibliograf, 1995.

BROSSARD, Sébastien de. Dictionnaire de Musique. $2^{a}$ edição. Paris: chez C. Ballard, 1705.

CAHUSAC, Jean Louis de. Basse-contre. In: D'ALEMBERT, Jean Le Rond; DIDEROT, D. (Org.) Encyclopédie, ou dictionnaire raisonné des sciences, des arts et des métiers. v. 2. Paris: Chez Briasson, David l'ainé, Le Breton, Durand, p. 120-121, 1751-1772. Disponível em <http://portail.atilf.fr/ encyclopedie/>. Acesso em: 30/12/2012.

Dictionnaire de l'Académie Française. Paris: Jean-Baptiste Coignard, 1694.

Dictionnaire universel françois et latin, vulgairement appelé Dictionnaire de Trévoux: contenant la signification et la définition tant des mots de l'une \& l'autre langue. $6^{a}$ edição. Paris: par la Compagnie des libraires associés, 1771.

DURON, Jean. Divertissement. In: BENOIT, Marcelle (Org.). Dictionnaire de la musique en France au XVII ${ }^{e}$ et XVIII siècles. Paris: Fayard, 1992.

FRANCHI, Saverio. (Org.). Percorsi dell'oratorio romano. Da "historia sacra" a melodramma spirituale. Roma: Ibimus, 2002.

GRIMAREST, Jean.-Léonor Le Gallois de. Traité du récitatif: dans la lecture, dans l'action publique, dans la déclamation, 
et dans le chant : avec un traité des accens, de la quantité, \& de la ponctuation. Paris: chez Jaques Le Fevre et Pierre Ribou, 1707.

HILL, John Walter. Oratory Music in Florence, III: The Confraternities from 1655 to 1785. In: Acta Musicologica, Basileia, v. 58, n. 1, p. 129-179, Jan.-Jun. 1986.

HOWARD, Patricia. Lully and the ironic convention. In: Cambridge Opera Journal, Cambridge, v. 1, n. 2, p. 139-153, Jul. 1989.

KIRKENDALE, Ursula. The Ruspoli Documents on Handel. In: Journal of the American Musicological Society, Berkeley (CA), v. 20, n. 2, p. 222-273, Summer 1967.

LECOMTE, Nathalie. Beauchamp, Pierre. In: BENOIT, Marcelle (Org.). Dictionnaire de la musique en France au XVII et XVIII ${ }^{e}$ siècles. Paris: Fayard, p. 61-62, 1992.

LECOMTE, Nathalie. Entrée. In: BENOIT, Marcelle (Org.). Dictionnaire de la musique en France au XVII et XVIII ${ }^{e}$ siècles. Paris: Fayard, 1992b.

LEGRAND, Raphaëlle. Dumenil. In: BENOIT, Marcelle (Org.). Dictionnaire de la musique en France au XVII et XVIII siècles. Paris: Fayard, 1992.

LEGRAND, Raphaëlle. Rochois. In: BENOIT, Marcelle (Org.). Dictionnaire de la musique en France au XVII et XVIII siècles. Paris: Fayard, 1992b.

MARTINELLI, Valentino. "Teatri Sacri e profani" di Andrea Pozzo nella cultura prospettico-scenografica barocca. In: FEO, Vittorio de; MARTINELLI, Valentino (Org.). Andrea Pozzo. Milão: Electa, p. 94-113, 1996.

MATTHESON, Johann. Der musicalischen Parallele, Erster Abriss., August 1722. In: MATTHESON, Johann. Critica Musica [1722-1725]. Laaber: Laaber-Verlag, 2003. 
NORMAN, Buford. P. Quinault, Livrets d'Opéra. Toulouse: Société de Littératures Classiques, 1999.

RAGUENET, François. A Comparison between the French and Italian Music. In: The Musical Quarterly, Oxford, vol. 32, n. 3, p. 411-436, jul. 1946.

RAGUENET, François. La Paix de L'Opéra, ou Parallèle impartial de la Musique Française et de la Musique italienne. Amsterdam: s/,1753. In LAUNAY, Denise (Org.). La Querelle des Bouffons. Textes de pamphlets avec introduction, commentaires et index. V.1. Genebra: Minkoff, p. 513-552, 1973.

ROSOW, Lois. Structure and Expression in the scènes of Rameau's Hippolyte et Aricie. In: Cambridge Opera Journal, Cambridge, v. 10, n. 3., p. 259-273, Nov. 1998.

ROUSSEAU, Jean-Jacques. Basse Chantante. In: ROUSSEAU, Jean-Jacques. Dictionnaire de Musique. In: Euvres Complètes de J.- J. Rousseau. Paris: Dalibon, p. 112$113,1826$.

SMITHER, Howard E. A History of the Oratorio: The Oratorio in the Baroque Era; Italy, Vienna, Paris. Chapel Hill: University of North Carolina Press, 1977. 